\title{
TECTONO-METAMORPHIC EVOLUTION AND TIMING OF THE MELTING PROCESSES IN THE SVECOFENNIAN TONALITE-TRONDHJEMITE MIGMATITE BELT: AN EXAMPLE FROM LUOPIOINEN, TAMPERE AREA, SOUTHERN FINLAND
}

\author{
H. MOURI, K. KORSMAN and H. HUHMA
}

MOURI, H., KORSMAN, K. and HUHMA, H. 1999. Tectono-metamorphic evolution and timing of the melting processes in the Svecofennian TonaliteTrondhjemite Migmatite Belt: An example from Luopioinen, Tampere area, southern Finland. Bulletin of the Geological Society of Finland 71, Part 1, 3156.

The Svecofennian Orogen is in southern Finland characterized by two major migmatite belts. These are the so-called Granite Migmatite Belt, in which Kfsrich leucosomes predominate, and the Tonalite-Trondhjemite Migmatite Belt, which is characterized by Kfs-poor leucosomes and borders the former belt in the north. The present paper deals with selected migmatitic rocks from the latter belt. It is aimed to study the temporal and structural relationships of the different leucosome generations, and to establish the pressure-temperature-time paths of this belt.

The Tonalite-Trondhjemite Migmatite Belt consists mainly of migmatitic rocks with various types of synorogenic granitoids and minor mafic and ultramafic rocks. The mesosome of the migmatites consist of garnet-sillimanite-biotite-plagioclase-cordierite-quartz assemblages with rare K-feldspar and late andalusite. The oldest leucosomes are dominated by plagioclase and quartz, and the content of K-feldspar increases in later leucosomes. Microtextural analysis in conjunction with THERMOCALC calculations and geothermometry shows that these rocks were metamorphosed at peak conditions of $700-750^{\circ} \mathrm{C}$ at $4-5 \mathrm{kbar}$ and $\mathrm{aH}_{2} \mathrm{O}=0.4-0.7$. The formation of cordierite coronas around garnet and the late crystallization of andalusite suggest that the final stage of the P-T history was characterized by decompression and cooling within the andalusite stability field, estimated at $500-650^{\circ} \mathrm{C}$ and $3-4 \mathrm{kbar}$.

Detailed isotopic dating of mesosome and leucosomes of the migmatites was undertaken by conventional $\mathrm{U}-\mathrm{Pb}$ analyses on monazite and zircon, $\mathrm{Sm}-\mathrm{Nd}$ analyses on garnet, and ion probe dating on zircon. The monazites are nearly concordant with an average age of $1878.5 \pm 1.5 \mathrm{Ma}$, and garnet-whole rock analyses show that the concordant leucosomes and the mesosome are coeval within error margins having ages of $1893 \pm 40$ and $1871 \pm 14 \mathrm{Ma}$, respectively. However, garnet in the discordant vein leucosome provides an age of $1843 \pm 11 \mathrm{Ma}$, which is marginally younger than the age of the adjacent mesosome and the concordant leucosome (1877 \pm 18 and $1880 \pm 23 \mathrm{Ma}$, respectively) and the age of monazite. Zircons from the studied migmatites display complex zoning structures using SEM-based CL-imaging. Most grains have distinct cores, clearly remnants of original grains. The cores display various types of zoning but oscillatory zon- 
ing dominates. The cores are overgrown by one or two thin outer rims that are of two types: i) unzoned outer rim, considered as overgrowth of new zircon during a metamorphic event, and ii) weakly oscillatory zoned rim, considered as typical of magmatic recrystallization. Ion probe dating of cores yielded slightly discordant ${ }^{207} \mathrm{~Pb} / 206 \mathrm{~Pb}$ ages of between $2866-2002 \mathrm{Ma}$, which are interpreted as protolith age. Rims yielded two major age groups: the unzoned rims gave ages of 1872-1886 Ma, whereas the rims with oscillatory zoning yielded ages of 19511959 Ma. The youngest age group is consistent with the conventional Sm-Nd dating on garnet and $\mathrm{U}-\mathrm{Pb}$ dating on monazite and we suggest that the migmatites were metamorphosed at granulite facies conditions at ca. $1880 \mathrm{Ma}$. The 1951-1959 Ma age group yielded by magmatic zircon rims remains difficult to interpret, but may reflect a magmatic event prior to the metamorphic one. This magmatic event might be related to the rifting of a Svecofennian protocontinent.

Key words: migmatites, leucosomes, metamorphism, P-T conditions, partial melting, absolute age, $\mathrm{U} / \mathrm{Pb}$, monazite, zircon, $\mathrm{Sm} / \mathrm{Nd}$, garnet group, Proterozoic, Luopioinen, Finland

Hassina Mouri: Geological Survey of Finland, P.O. Box 96, FIN-02151 Espoo, Finland and Department of Geology, P.O. Box 11 (Snellmaninkatu 3), FIN-00014 University of Helsinki, Finland.

E-mail:hmouri@yahoo.com

Kalevi Korsman and Hannu Huhma: Geological Survey of Finland, P.O. Box 96, FIN-02151 Espoo, Finland.

E-mails: kalevi.korsman@gsf.fi hannu.huhma@gsf.fi

\section{INTRODUCTION AND GEOLOGICAL FEATURES OF THE STUDY AREA}

The Svecofennian Orogen is in southern Finland characterized by the Tonalite-Trondhjemite Migmatite Belt with mainly psammitic palaeosomes and southwards from it by the Granite Migmatite Belt with mainly pelitic palaeosomes. In this paper we will focus specifically on the TonaliteTrondhjemite Migmatite Belt characterized by Kfs-poor leucosomes. Although the relative timing of deformation and magmatism has been well established in this belt, the exact age of the metamorphic events and melting processes have been uncertain. The study aims at establishing the P-T evolution of these migmatitic rocks, the relationship between the different leucosome generations, and their origin and the time scale of partial melting using conventional $\mathrm{U}-\mathrm{Pb}$ and $\mathrm{Sm}-\mathrm{Nd}$ methods on monazite, zircon and garnet as well as ion probe dating on zircon.

The Tonalite-Trondhjemite Migmatite Belt with Kfs-poor leucosomes belongs to the Central Fin- land Arc Complex (Fig. 1 and Korsman et al. 1997a). The belt is bordered in the south by the Granite Migmatite Belt, where the age of metamorphism is $1.810-1.830 \mathrm{Ga}$, and in the north by the Central Finland Granitoid Complex in which the granitoids are 1.888-1.870 Ga old (Korsman et al. 1997b). The granitoid complex is separated from the trondhjemite migmatites by the Tampere Schist Belt largely composed of 1.904-1.889 Ga old arc-type volcanic rocks (Kähkönen et al. 1989). The Tonalite-Trondhjemite Migmatite Belt includes mafic and ultramafic metalavas that are possibly close to the Haveri metabasalts of the Tampere Schist Belt in age; Vaasjoki and Huhma (1999) yielded whole rock $\mathrm{Pb}-\mathrm{Pb}$ model ages of 1.9-2.0 Ga for the latter. These volcanic rocks have been interpreted to represent a rifting stage of a Svecofennian protocontinent prior to $1.91 \mathrm{Ga}$ (Lahtinen 1994). Arc-type volcanic rocks have not been found within the migmatite belt, but nickelbearing mafic and ultramafic cumulates dated at $1.89 \mathrm{Ga}$ do occur (Peltonen 1995). The migmatite belt and the Tampere Schist Belt comprise also 


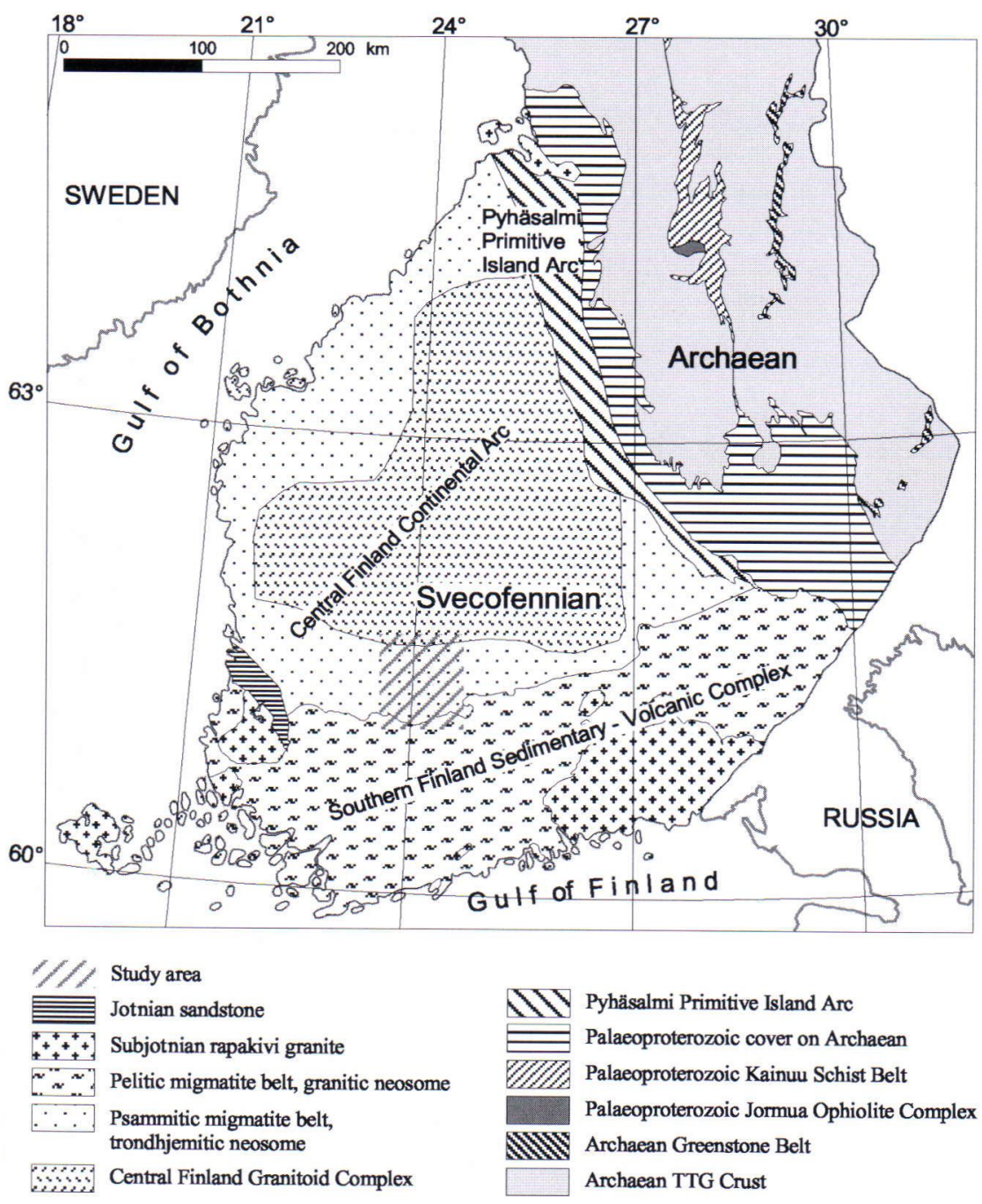

Fig. 1. The main geotec. tonic units of southern anc central Finland after Kors. man et al. (1999) and the location of the study area. tonalites, quartz diorites and granodiorites with $\mathrm{U}$ $\mathrm{Pb}$ zircon ages of 1.89-1.87 Ga (Nironen 1989, Kilpeläinen 1998).

The Svecofennian crust is characterized by lowpressure/high-temperature metamorphism (Glebovitskiy 1970, Korsman 1977). Earlier, in the Tonalite-Trondhjemite Migmatite Belt, the age of metamorphism has been determined by studying the relationships between growth of porphyroblasts, deformation stages and intrusion events of granitoids dated by the U-Pb method on zircon (e.g. Kilpeläinen et al. 1994). The age of the hightemperature metamorphism has been considered to be $1885 \mathrm{Ma}$. The low-P/high-T metamorphism is caused by extensive magma underplating and has taken place during and soon after subduction and crustal thickening (Korsman et al. 1999).

\section{SAMPLES AND PETROGRAPHY}

The nomenclature proposed for migmatites by Mehnert (1968), extended by Johannes and Gupta (1982), and applied by Brown (1983) and Jones and Brown (1990) is used in this paper. The studied migmatites are mainly metatexites and exhib- 
it a stromatic-banded structure: mesosome with layers, veins and patches of leucosomes (Figs. 2a, $\mathrm{b}$ and $\mathrm{c}$ ). The migmatites are characterized by Kfspoor leucosomes with a slight increase in the proportion of K-feldspar from Kfs-poor leucosome through mildly Kfs-enriched type to granitic leucosome.

This work focuses on two typical outcrops of the Tonalite-Trondhjemite Migmatite Belt at Luopioinen. The outcrops are largely composed of banded palaeosome with psammitic and, in places, pelitic layers. Different types of anastomosing leucosomes are identified on the basis of field relationships (Figs. 2a and b). These leucosomes (L1, L2, L3 and L-granite, see below) are typical for the whole Tonalite-Trondhjemite Migmatite Belt.

\section{Mesosome}

The mesosome is fine to coarse grained with equigranular texture and contains quartz, biotite, plagioclase, garnet, sillimanite, cordierite, late muscovite, andalusite and chlorite together with rare K-feldspar.

Biotite is abundant (34-36 vol\%) (Table 1) and occurs in two associations: i) with sillimanite in the main foliation plane (Fig. 2d), and ii) as randomly distributed in the matrix in association with either cordierite and sillimanite (Fig. 2e) or quartz and plagioclase. The biotite sometimes contains zones of fine-grained opaque inclusions within individual flakes and between adjacent flakes. These features are similar to those noted in melting experiments (e.g. Busch et al. 1974), partially molten rocks and high-grade migmatites (e.g. Brown 1979). This suggests instability and the features appear to occur at the commencement of biotite breakdown, possibly due to incongruent melting (Brown 1983).

Garnet occurs as porphyroblasts (Figs. 2a and b) and contains rare inclusions of quartz, biotite, plagioclase and sillimanite. The garnet is often rimmed by cordierite (Fig. 2d) which isolates it from the main foliation composed of biotite and sillimanite.

Cordierite (up to $2 \mathrm{~mm}$ in diameter) is observed in two settings: i) as well-developed coronas to- gether with plagioclase between garnet and sillimanite-biotite (Fig. 2d) and ii) in garnet-free microdomains together with plagioclase and containing sillimanite and biotite inclusions (Fig. 2e).

Plagioclase is moderately abundant (15-30 vol\%) and has been observed in four settings: i) as rare and small inclusions in garnet, ii) in the matrix as associated with cordierite, iii) in some cordierite coronas, and iv) in the main foliation plane with sillimanite and biotite.

$\mathrm{K}$-feldspar occurs in the matrix as an interstitial phase in equilibrium with plagioclase, but never in equilibrium with cordierite or garnet.

\section{Leucosomes}

The L1 leucosome occurs as layers parallel to the mesosome layers (Figs. 2a and b) and varies from $1 \mathrm{~mm}$ to $10 \mathrm{~cm}$ in thickness. The L1 leucosome is deformed in places and characterized by low abundances of K-feldspar ( 1 vol\%). The major minerals are, in decreasing abundance (Table 1), quartz with anhedral, sutured grain boundaries, polygonal plagioclase, and subhedral grains of biotite. In addition, rare rounded fragmented garnet develops at the boundaries between leucosome and mesosome. In some microdomains sillimanite occurs as needles within plagioclase. Minor components are opaque minerals, zircon, monazite, secondary chlorite, and muscovite.

The L2 leucosome is slightly discordant with respect to the country rock foliation (Fig. 2a). It occurs as a vein ranging from a few $\mathrm{cm}$ to less

Fig. 2. $a, b$ and $c$ : Photographs showing field relationships between leucosomes L1, L2 and L-granite and the mesosome. $d$-h: Photomicrographs on textures within mesosome and leucosomes, width of field $4 \mathrm{~mm}$. $d$. Texture of mesosome showing garnet with inclusions of quartz and surrounded by a corona of cordierite separating it from quartz and the main foliation of biotite+sillimanite. e. Cordierite in matrix with inclusions of sillimanite and biotite. $f$. Garnet in discordant leucosome vein ( $L 2)$, surrounded by sillimanite + biotite and with late muscovite and chlorite in fractures. $g$. Large cordierite in cordierite-bearing leucosome (L3) showing magmatic texture. h. Typical texture of leucosomes; plagioclase with crystal faces against quartz. 

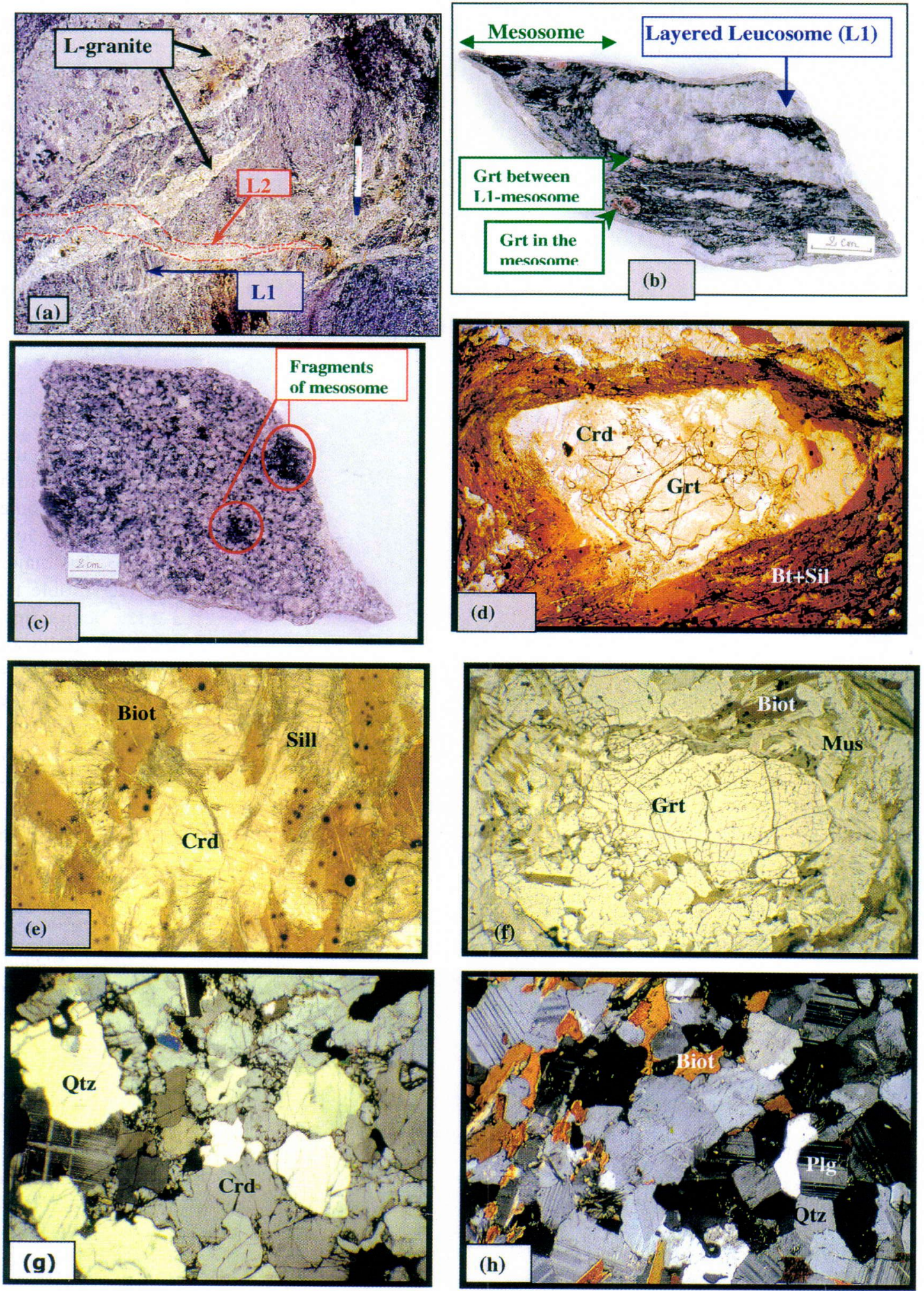
Table 1. Modal proportions of different phases in the mesosome and leucosomes of the studied migmatites.

\begin{tabular}{lcccccc}
\hline & $\% \mathrm{Kfs}$ & $\% \mathrm{Pl}$ & $\% \mathrm{Bt}$ & $\% \mathrm{Qtz}$ & $\% \mathrm{Grt}$ & $\%$ Sil \\
\hline Mesosome & $1-5$ & $14-29$ & $34-36$ & $34-39$ & $1-2$ & $1-3$ \\
Layered leucosome (L1) & $<1$ & $40-45$ & $4-6$ & $44-46$ & $<1$ & 0 \\
Leucosome vein (L2) & $10-11$ & $40-42$ & $21-23$ & $23-25$ & $<1$ & $<1$ \\
Crd-leucosome (L3) & $13-15$ & $36-38$ & $18-20$ & $26-27$ & 0 & 0 \\
L-granite & $42-44$ & $23-25$ & $2-4$ & $26-28$ & 0 & $<1$ \\
\hline
\end{tabular}

than $1 \mathrm{~m}$ in thickness and cuts across the L1 leucosome and the mesosome. The texture is more coarse grained and more inequigranular than in the L1 leucosome. The L2 leucosome also contains much more K-feldspar (10 vol\%) than L1. Plagioclase, quartz and biotite are the most abundant phases (Table 1). Rare xenocrysts of garnet ( $<1 \mathrm{~mm}$ in diameter) occur, invariably in contact with biotite, with very rare needles of sillimanite and late muscovite (Fig. 2f). No cordierite coronas were found around garnet.

The cordierite-bearing leucosome L3 is different from the former types; it occurs as rare small patches overprinting the main foliation. This leucosome is characterized by polygonal plagioclase, quartz and interstitial K-feldspar (13 to 15 vol\%) together with magmatic cordierite (Fig. $2 \mathrm{~g}$ ) commonly occurring as large $(1 \mathrm{~cm})$, optically continuous poikiloblastic crystals.

The L-granite is rare and occurs as a ca. $50 \mathrm{~cm}$ wide vein discordant with respect to the country rock structures and cutting sharply across the mes- osome and leucosomes L1 and L2 (Fig. 2a). The texture is very coarse grained, almost pegmatitic and is mainly comprised of large crystals of $\mathrm{K}$ feldspar (44 vol\%) (Table 1), euhedral to subhedral quartz, myrmekitic plagioclase, very rare prisms of biotite and, thin needles of sillimanite.

All the leucosomes show similar microstructures, characterized by euhedral crystals of plagioclase with crystal faces against quartz (Fig. 2h). In addition, the L2 leucosome is characterized by zoning of plagioclase. Textural features suggest that the leucosomes L1, L2, L3 and L-granite crystallized from melt (e.g. Vernon \& Collins 1988).

\section{Mineral chemistry}

Representative analyses of minerals from the mesosome and different types of leucosomes are listed in Tables 2 and 3. Mineral compositions were obtained with a CamecaCamebax SX-50 electron microprobe at the Geological Survey of Finland and at the CAMPARIS centre (University of Paris VI). The operating conditions were $20 \mathrm{nA}$ beam current with an accelerating voltage of $15 \mathrm{kV}$ and 1

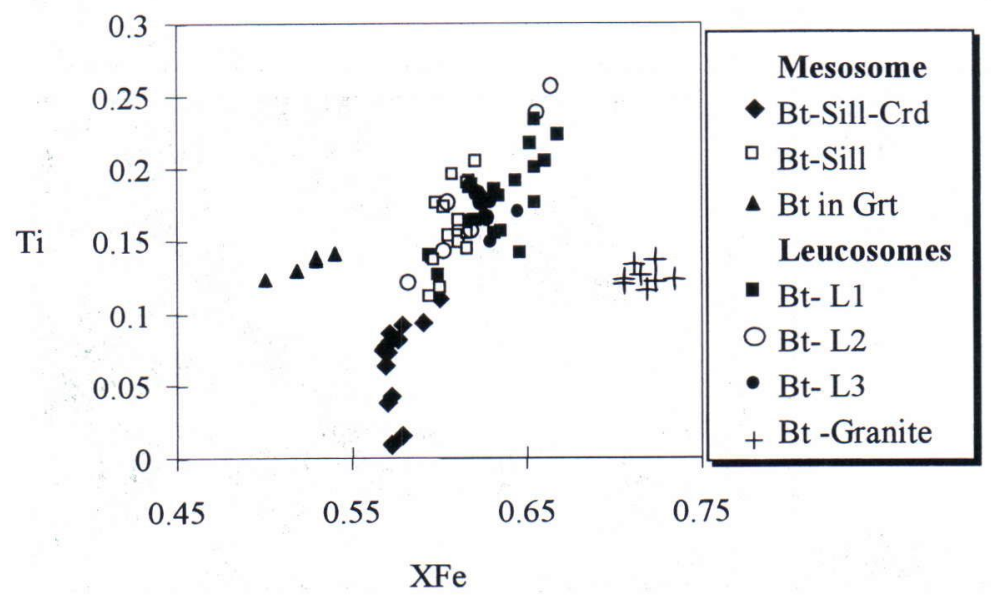

Fig. 3. Ti vs. $X_{F e}$ diagram of biotite from the mesosome and the adjacent leucosomes. 
Table 2. Representative chemical compositions of biotite in the mesosome and adjacent leucosomes.

\begin{tabular}{|c|c|c|c|c|c|c|c|c|c|c|c|c|}
\hline & \multicolumn{5}{|c|}{ Biotite in the mesosome } & \multicolumn{2}{|c|}{$\mathrm{Bt}$ in $\mathrm{L} 1$} & \multicolumn{3}{|c|}{$\mathrm{Bt}$ in $\mathrm{L} 2$} & \multicolumn{2}{|c|}{$\mathrm{Bt}$ in L-granite } \\
\hline & $\mathrm{Bt}(\mathrm{f})$ & $\mathrm{Bt}(\mathrm{m} 1)$ & $\mathrm{Bt} / \mathrm{crdc}$ & $\mathrm{Bt}(\mathrm{m} 2)$ & & $\mathrm{Bt}(\mathrm{m} 2)$ & & core & $\mathrm{rim} / \mathrm{grt}$ & $\mathrm{Bt}(\mathrm{m} 2)$ & $\mathrm{Bt}(\mathrm{m} 2)$ & \\
\hline $\mathrm{SiO}_{2}$ & 34.94 & 35.26 & 35.00 & 34.00 & 34.00 & 34.00 & 34.81 & 34.39 & 34.41 & 34.92 & 34.19 & 34.01 \\
\hline $\mathrm{TiO}_{2}$ & 2.42 & 0.27 & 3.00 & 3.00 & 4.00 & 3.00 & 4.16 & 0.8 & 0.14 & 3.28 & 2.08 & 2.10 \\
\hline $\mathrm{Al}_{2} \mathrm{O}_{3}$ & 19.72 & 21.34 & 19.00 & 19.00 & 19.00 & 18.00 & 19.14 & 20.79 & 21.69 & 18.51 & 20.53 & 20.01 \\
\hline $\mathrm{Cr}_{2} \mathrm{O}_{3}$ & 0.1 & 0.02 & 0.00 & 0.00 & 0.00 & 0.00 & 0.16 & 0.06 & 0.08 & 0.01 & 0.00 & 0.00 \\
\hline $\mathrm{MgO}$ & 7.94 & 8.56 & 8.00 & 7.00 & 6.00 & 8.00 & 6.52 & 8.43 & 8.84 & 7.38 & 5.56 & 5.00 \\
\hline $\mathrm{FeO}$ & 20.85 & 20.98 & 21.00 & 22.00 & 22.00 & 22.00 & 22.21 & 20.98 & 20.74 & 21.11 & 23.61 & 24.60 \\
\hline $\mathrm{MnO}$ & 0.09 & 0.04 & 0.00 & 0.00 & 0.00 & 0.00 & 0.05 & 0.1 & 0.12 & 0.17 & 0.31 & 0.34 \\
\hline $\mathrm{CaO}$ & 0.01 & 0 & 0.00 & 0.00 & 0.00 & 0.00 & 0.01 & 0.02 & 0 & 0.01 & 0.01 & 0.02 \\
\hline $\mathrm{BaO}$ & 0 & 0.07 & 0.00 & 0.00 & 0.00 & 0.00 & 0.39 & 0 & 0 & 0 & 0.00 & 0.00 \\
\hline $\mathrm{Na}_{2} \mathrm{O}$ & 0.22 & 0.3 & 0.00 & 0.00 & 0.00 & 0.00 & 0.13 & 0.2 & 0.19 & 0.17 & 0.13 & 0.07 \\
\hline $\mathrm{K}_{2} \mathrm{O}$ & 9.44 & 9.07 & 9.00 & 9.00 & 9.00 & 8.00 & 9.35 & 9.05 & 9.07 & 9.81 & 9.58 & 9.78 \\
\hline Sum & 95.73 & 95.91 & 95.00 & 94.00 & 94.00 & 93.00 & 96.93 & 94.82 & 95.28 & 95.37 & 96.00 & 95.93 \\
\hline $\mathrm{Si}$ & 667 & 2.673 & 2.67 & 2.66 & 2.67 & 2.7 & 2.65 & 2.645 & 2.627 & 2.689 & 2.64 & 2.65 \\
\hline $\mathrm{Ti}$ & 0.139 & 0.015 & 0.17 & 0.16 & 0.21 & 0.15 & 0.24 & 0.046 & 0.008 & 0.19 & 0.12 & 0.12 \\
\hline $\mathrm{Al}$ & 1.774 & 1.907 & 1.73 & 1.76 & 1.72 & 1.71 & 1.72 & 1.885 & 1.952 & 1.68 & 1.87 & 1.84 \\
\hline $\mathrm{Cr}$ & 0.006 & 0.001 & 0.00 & 0.00 & 0.01 & 0.01 & 0.01 & 0.004 & 0.005 & 0 & 0.00 & 0.00 \\
\hline $\mathrm{Mg}$ & 0.903 & 0.967 & 0.89 & 0.82 & 0.74 & 0.89 & 0.74 & 0.966 & 1.006 & 0.847 & 0.64 & 0.58 \\
\hline $\mathrm{Fe}_{2}$ & 1.331 & 1.33 & 1.35 & 1.43 & 1.44 & 1.43 & 1.41 & 1.349 & 1.324 & 1.36 & 1.53 & 1.60 \\
\hline $\mathrm{Mn}$ & 0.006 & 0.003 & 0.01 & 0.00 & 0.01 & 0.01 & 0.00 & 0.006 & 0.008 & 0.011 & 0.02 & 0.02 \\
\hline $\mathrm{Ca}$ & 0.001 & 0 & 0.00 & 0.00 & 0.00 & 0.00 & 0.00 & 0.001 & 0 & 0.001 & 0.00 & 0.00 \\
\hline $\mathrm{Ba}$ & 0 & 0.002 & 0.01 & 0.01 & 0.00 & 0.00 & 0.01 & 0 & 0 & 0 & 0.00 & 0.00 \\
\hline $\mathrm{Na}$ & 0.033 & 0.044 & 0.02 & 0.02 & 0.02 & 0.02 & 0.02 & 0.03 & 0.029 & 0.025 & 0.02 & 0.01 \\
\hline K & 0.919 & 0.877 & 0.90 & 0.91 & 0.90 & 0.81 & 0.91 & 0.888 & 0.883 & 0.964 & 0.94 & 0.97 \\
\hline Sum & 7.779 & 7.819 & 7.75 & 7.77 & 7.72 & 7.73 & 7.71 & 7.82 & 7.842 & 7.767 & 7.78 & 7.80 \\
\hline $\mathrm{X}_{\mathrm{Fe}}$ & 0.596 & 0.579 & 0.600 & 0.640 & 0.660 & 0.620 & 0.656 & 0.583 & 0.568 & 0.616 & 0.705 & 0.734 \\
\hline
\end{tabular}

$\mathrm{Bt}(\mathrm{f})=$ biotite in the foliation plane with sillimanite

$\mathrm{Bt}(\mathrm{m} 1)=$ biotite in the matrix with sillimanite+cordierite

$\mathrm{Bt} / \mathrm{crdc}=$ biotite with cordierite corona

$\mathrm{Bt}(\mathrm{m} 2)=$ biotite in the matrix with plagioclase and quartz

to $15 \mathrm{~mm}$ beam widths depending on the minerals. Natural silicates and synthetic oxides were used as standards for all elements, except for fluorine for which fluorite was used.

Biotite in the mesosome and leucosomes is compositionally heterogeneous (Table 2, Fig. 3), $\mathrm{X}_{\mathrm{Fe}}$ ranges between 0.50 and 0.73 and $\mathrm{TiO}_{2}$ between 0 and $4.16 \mathrm{wt} \%$. Biotites in the leucosomes are relatively higher in iron $\left(\mathrm{X}_{\mathrm{Fe}}=0.60\right.$ $0.73)$ than those in the mesosome $\left(\mathrm{X}_{\mathrm{Fe}}=0.50-0.60\right)$, whereas $\mathrm{Al}_{2} \mathrm{O}_{3}$ in all samples shows a similar range between 18 and $20 \mathrm{wt} \%$. The $\mathrm{TiO}_{2}$ content is slightly higher in leucosomes L1 and L2 (3-4 wt\%) than in mesosome and L-granite $(0-3 \mathrm{wt} \%)$. Small but significant differences in biotite composition are found in mesosome and L2 leucosome. Biotite inclusions in garnet have slightly lower $\mathrm{X}_{\mathrm{Fe}}(0.52-$ $0.54)$ than biotite associated with sillimanite and cordierite in the matrix $\left(\mathrm{X}_{\mathrm{Fe}}=0.56-0.58\right)$ and biotite in the main foliation plane $\left(\mathrm{X}_{\mathrm{Fe}}=0.59-0.60\right)$. Biotite from the L2 leucosome is also heterogeneous in composition: biotite in contact with garnet has $\mathrm{X}_{\mathrm{Fe}}$ of $0.57-0.59$, similar to that of biotite in the mesosome, whereas biotite in the matrix with plagioclase and quartz has higher $\mathrm{X}_{\mathrm{Fe}}$ of $0.60-0.62$.

Garnet in both mesosome and leucosomes is almandine rich with $\mathrm{X}_{\mathrm{Fe}}$ values ranging between 0.82 and 0.90 (Table 3 and Fig. 4). In both cases the garnets are characterized by unzoned core with a slight enrichment in Fe towards the rim and a depletion in $\mathrm{Mg}$ (Table 3). Such patterns are typical of garnet in high-grade rocks indicating that the garnets were primarily homogeneous, and that subsequent diffusion at the rim has modified the composition during retrogression (Spear 1993). The proportions of spessartine and grossularite are very low (ca. 2.5 and 1.5 wt $\%$, respectively). Garnet from the leucosomes is characterized by a sharp increase in $\mathrm{Mn}$ on approaching the edge (Fig. 4). This has been interpreted as back diffusion (e.g. Selverstone \& Hollister 1980). The similarity of garnet composition in both mesosome and leucosomes supports the idea that garnet was mechanically introduced into the leucosomes.

Cordierite is compositionally heterogeneous (Table 3): 
Table 3. Representative chemical compositions of garnet and cordierite in the mesosome, adjacent discordant leucosome vein (L2) and leucosome L3.

\begin{tabular}{|c|c|c|c|c|c|c|c|c|c|c|c|}
\hline \multirow[b]{3}{*}{$\mathrm{SiO}_{2}$} & \multicolumn{2}{|c|}{ Mesosome } & \multicolumn{2}{|c|}{ Leucosome (L2) } & & \multicolumn{4}{|c|}{ Crd in the mesosome } & \multirow{2}{*}{\multicolumn{2}{|c|}{$\frac{\text { Crd- L3 }}{\text { Crd/Pl-Kfs-Qtz }}$}} \\
\hline & \multirow{2}{*}{$\begin{array}{l}\text { Core } \\
36.82\end{array}$} & \multirow{2}{*}{$\frac{\operatorname{Rim}}{36.53}$} & \multirow{2}{*}{$\begin{array}{l}\text { Core } \\
36.93\end{array}$} & \multirow{2}{*}{$\begin{array}{c}\text { Rim } \\
37.40\end{array}$} & \multirow[b]{2}{*}{$\mathrm{SiO}_{2}$} & \multicolumn{2}{|c|}{ Crd corona/grt } & \multicolumn{2}{|c|}{ Crd with sill+Bt } & & \\
\hline & & & & & & 47.92 & 48.31 & 48.92 & 48.39 & 48.51 & 48.70 \\
\hline $\mathrm{TiO}_{2}$ & 0.02 & 0.03 & 0.00 & 0.02 & $\mathrm{TiO}_{2}$ & 0.00 & 0.02 & 0.00 & 0.00 & 0.01 & 0.00 \\
\hline $\mathrm{Al}_{2} \mathrm{O}_{3}$ & 20.53 & 20.50 & 20.82 & 20.75 & $\mathrm{Al}_{2} \mathrm{O}_{3}$ & 31.70 & 31.70 & 32.26 & 32.05 & 31.83 & 33.19 \\
\hline $\mathrm{Cr}_{2} \mathrm{O}_{3}$ & 0.00 & 0.06 & 0.01 & 0.01 & $\mathrm{Cr}_{2} \mathrm{O}_{3}$ & 0.00 & 0.00 & 0.03 & 0.05 & 0.00 & 0.00 \\
\hline $\mathrm{Fe}_{2} \mathrm{O}_{3}$ & 0.50 & 0.06 & 0.91 & 0.00 & $\mathrm{MgO}$ & 6.04 & 6.58 & 7.30 & 7.01 & 6.89 & 7.61 \\
\hline $\mathrm{MgO}$ & 4.04 & 2.27 & 3.64 & 2.88 & $\mathrm{FeO}$ & 11.53 & 10.85 & 9.33 & 9.82 & 9.92 & 9.03 \\
\hline $\mathrm{FeO}$ & 34.22 & 37.02 & 34.98 & 37.07 & $\mathrm{MnO}$ & 0.24 & 0.14 & 0.18 & 0.20 & 0.20 & 0.01 \\
\hline $\mathrm{MnO}$ & 1.23 & 1.29 & 1.06 & 1.21 & $\mathrm{CaO}$ & 0.01 & 0.00 & 0.02 & 0.02 & 0.03 & 0.00 \\
\hline $\mathrm{CaO}$ & 1.03 & 0.89 & 1.15 & 0.91 & $\mathrm{Na}_{2} \mathrm{O}$ & 0.27 & 0.25 & 0.25 & 0.26 & 0.38 & 0.20 \\
\hline $\mathrm{Na}_{2} \mathrm{O}$ & 0.01 & 0.03 & 0.01 & 0.01 & $\mathrm{~K}_{2} \mathrm{O}$ & 0.01 & 0.15 & 0.03 & 0.00 & 0.00 & 0.00 \\
\hline $\mathrm{K}_{2} \mathrm{O}$ & 0.00 & 0.01 & 0.03 & 0.01 & & & & & & & \\
\hline Sum & 98.40 & 98.69 & 99.54 & 100.27 & Sum & 97.72 & 98.00 & 98.32 & 97.80 & 97.78 & 98.75 \\
\hline $\mathrm{Si}$ & 2.999 & 3.004 & 2.983 & 3.015 & $\mathrm{Si}$ & 5.044 & 5.055 & 5.060 & 5.046 & 5.063 & 5.004 \\
\hline $\mathrm{Ti}$ & 0.001 & 0.002 & 0.000 & 0.001 & $\mathrm{Ti}$ & 0.000 & 0.002 & 0.000 & 0.000 & 0.001 & 0.000 \\
\hline $\mathrm{Al}$ & 1.971 & 1.987 & 1.983 & 1.972 & $\mathrm{Al}$ & 3.933 & 3.909 & 3.933 & 3.939 & 3.916 & 4.019 \\
\hline $\mathrm{Cr}$ & 0.000 & 0.004 & 0.000 & 0.001 & $\mathrm{Cr}$ & 0.000 & 0.000 & 0.002 & 0.004 & 0.000 & 0.000 \\
\hline $\mathrm{Fe}_{3}$ & 0.031 & 0.004 & 0.055 & 0.000 & $\mathrm{Mg}$ & 0.948 & 1.026 & 1.126 & 1.090 & 1.072 & 1.165 \\
\hline $\mathrm{Mg}$ & 0.491 & 0.278 & 0.438 & 0.346 & $\mathrm{Fe}_{2}$ & 1.015 & 0.949 & 0.807 & 0.856 & 0.866 & 0.776 \\
\hline $\mathrm{Fe}_{2}$ & 2.331 & 2.546 & 2.363 & 2.499 & $\mathrm{Mn}$ & 0.021 & 0.012 & 0.016 & 0.018 & 0.018 & 0.001 \\
\hline $\mathrm{Mn}$ & 0.085 & 0.090 & 0.073 & 0.083 & $\mathrm{Ca}$ & 0.001 & 0.000 & 0.002 & 0.002 & 0.003 & 0.000 \\
\hline $\mathrm{Ca}$ & 0.090 & 0.079 & 0.100 & 0.079 & $\mathrm{Na}$ & 0.055 & 0.051 & 0.050 & 0.053 & 0.077 & 0.041 \\
\hline $\mathrm{Na}$ & 0.002 & 0.005 & 0.002 & 0.002 & $\mathrm{~K}$ & 0.001 & 0.020 & 0.004 & 0.000 & 0.000 & 0.000 \\
\hline K & 0.000 & 0.001 & 0.003 & 0.001 & & & & & & & \\
\hline Sum & 8.000 & 8.000 & 8.000 & 7.998 & Sum & 11.01 & 11.02 & 11.00 & 11.00 & 11.01 & 11.00 \\
\hline $\mathrm{X}_{\mathrm{Fe}}$ & 0.826 & 0.902 & 0.844 & 0.878 & $\mathrm{XFe}$ & 0.51 & 0.48 & 0.41 & 0.44 & 0.44 & 0.40 \\
\hline
\end{tabular}

the cordierite coronas around garnets are iron rich $\left(\mathrm{X}_{\mathrm{Fe}}=\right.$ 0.48-0.51), whereas the cordierite containing inclusions of sillimanite+biotite and the cordierite from the L3 leucosome have relatively low $\mathrm{X}_{\mathrm{Fe}}(0.40-0.45)$.

Plagioclases in the mesosome, L1 leucosome and Lgranite are homogeneous in composition, while in the L2 leucosome homogeneous and normally zoned plagioclase grains are present. In the mesosome and in the L1 and L2 leucosomes $\mathrm{X}_{\mathrm{an}}$ varies over a large range (0.18-0.34). Plagioclase from the L-granite is sodic with $\mathrm{X}_{\mathrm{an}}$ of $0.16-0.18$. Plagioclase inclusions in garnet are very low in $\mathrm{X}_{\mathrm{an}}(0.05)$.

\section{REACTION TEXTURES AND CRYSTALLI- ZATION CONDITIONS}

\section{Reactions}

The textures observed in the mesosome and the formation of the different types of leucosomes can be explained by progressive partial melting reactions during increasing temperature and decom- pression. Garnet could have been formed at the first stage of the melting process as follows:

$$
\mathrm{Pl}+\mathrm{Qtz}+\mathrm{Bt}+\mathrm{Sil} \rightarrow \mathrm{Grt}+\text { melt }
$$

The presence of rare remnant sillimanite, biotite, quartz and albite-rich plagioclase inclusions within garnet indicates that all these phases are involved in this melting reaction. However, because garnet is not abundant in the studied migmatites (1-2 vol\%) and because the leucosomes are Kfs-poor but plagioclase- and quartz-rich, we suggest that melting reaction (1) involves mainly the two last phases. Although biotite is considered as a minor phase during this melting stage, $\mathrm{K}$-feldspar is one of the expected products, but has not been found in equilibrium with garnet in the mesosome; it is present in the leucosomes in different proportions (Table 1). This could be explained by removal of 
K-component or mobilization at the scale of thin section and crystallization within melt fraction.

The melt formed by reaction (1) could correspond to the composition of the L1 and L2 leucosomes since garnet is found in both leucosomes. The conditions of the formation of the L1 and L2 leucosomes and the significance of the difference in the proportion of K-feldspar in these two leucosomes will be discussed in the next section.

The cordierite coronas around garnets could be explained by the breakdown of garnet, sillimanite and quartz:

$$
\mathrm{Grt}+\mathrm{Sil}+\mathrm{Qtz}+(\mathrm{Bt} 1) \rightarrow \mathrm{Crd}+(\mathrm{Bt})
$$

The rare small biotites associated with cordierite could indicate either the breakdown of an early biotite phase (Bt1) or the presence of K-rich fluid.

The cordierite in the matrix of the mesosome and in the L3 leucosome patches differs in composition and texture from the cordierite in the coronas. This cordierite could be a peritectic phase formed by an incongruent melting reaction of biotite at the final stage of partial melting:

$$
\mathrm{Pl}+\mathrm{Bt}+\mathrm{Sil}+\mathrm{Qtz} \rightarrow \mathrm{Crd}+\text { melt }
$$

The melt composition in equilibrium with cordierite could correspond to the composition of the L3 leucosome. K-feldspar is not observed in the matrix of the mesosome, but occurs only in the L3 leucosome as an interstitial phase in equilibrium with cordierite and in higher proportion (12-15 vol\%) than in the L1 and L2 leucosomes. This suggests removal of potassium component from the mesosome during melting.

\section{Crystallization conditions}

In order to discuss the metamorphic evolution of the studied migmatites, all the observed assemblages are represented in an appropriate thermodynamic NKFMASH system (e.g. Powell \& Holland 1988). To interpret the observed melting reactions and to understand the relationships between leucosomes and mesosome, bulk compositions of the L1, L2, L3 and L-granite leucosomes

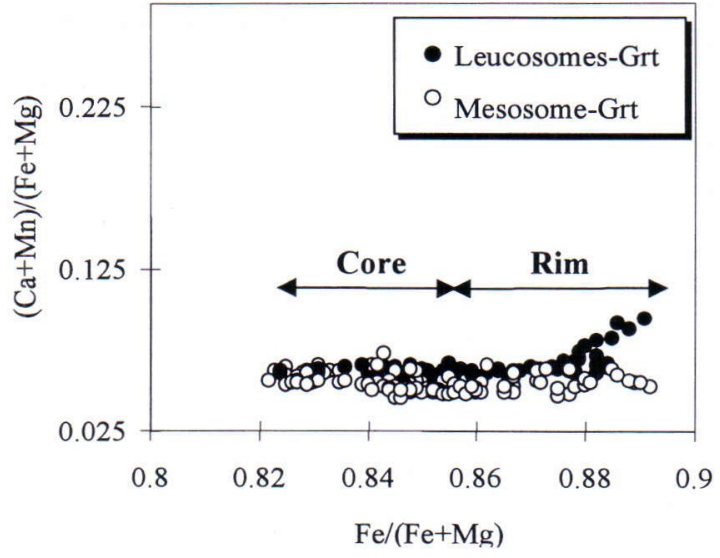

Fig. 4. $(\mathrm{Ca}+\mathrm{Mn}) /(\mathrm{Fe}+\mathrm{Mg})$ vs. $\mathrm{X}_{\mathrm{Fe}}$ in garnets from the mesosome and the discordant leucosome vein (L2).

are projected on the same compatibility diagram with the mesosome paragenesis (Fig. 5). As a first approximation, water is considered to be in excess together with Pl, Sil and Qtz and all these phases are used as projection phases to reduce the system NKFMASH to KFM. The $\mathrm{K} /(\mathrm{Fe}+\mathrm{Mg})$ vs. Fe/ $(\mathrm{Fe}+\mathrm{Mg}$ ) diagram (Fig. 5) shows that, firstly, all the observed reaction textures (1), (2) and (3) correspond to continuous equilibria in the NKFMASH system. These equilibria are represented by triangles in the compatibility diagram and correspond to different $\mathrm{P}-\mathrm{T}$ domains separated by univariant reactions. Secondly, the L1, L2 and L3 leucosome compositions are in equilibrium with the mesosome paragenesis and preclude equilibrium between the latter and L-granite. This could indicate that L1, L2 and L3 originated from the same source by in situ melting, whereas L-granite was formed either from the same source as L1, $\mathrm{L} 2$ and $\mathrm{L} 3$, but at different $\mathrm{P}-\mathrm{T}-\mathrm{aH}_{2} \mathrm{O}$ conditions, or represents an injection of melt from an external source. The last hypothesis is consistent with the sharp contacts of this vein (Fig. 2a). Therefore, it is likely that there is no direct genetic link between L-granite and the mesosome paragenesis. Thirdly, garnet is in equilibrium with L1 and L2, whereas cordierites in the matrix of the mesosome and in the L3 leucosome patches are in equilibrium with the latter. Therefore, L1 and L2 can be interpreted as resulting from the same reaction (1) 


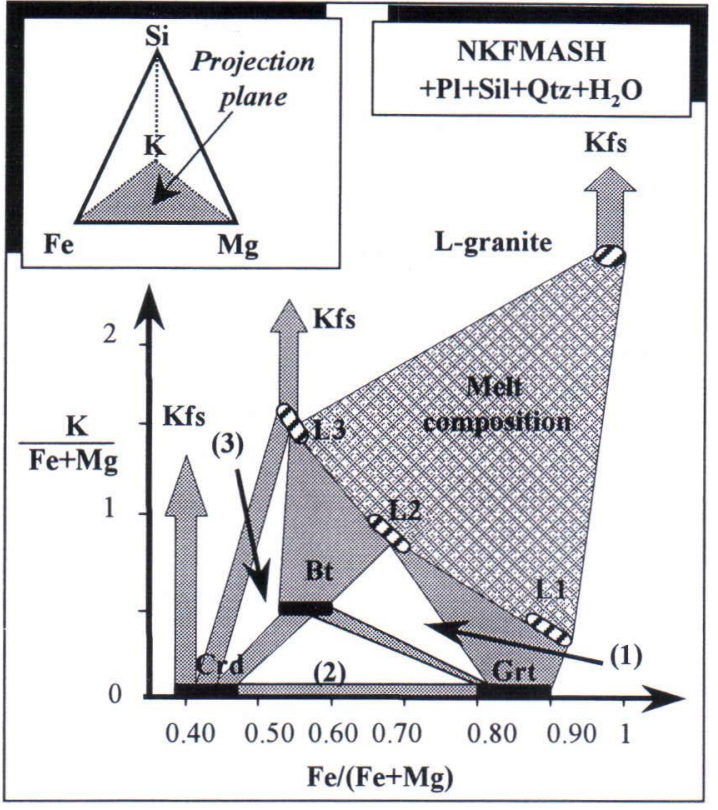

Fig. 5. Compatibility diagram in the system NKFMASH, projected from water, quartz, plagioclase and sillimanite, showing the phase relationships between the mesosome paragenesis and melt bulk rock compositions (leucosomes) and the interpretation of the observed reaction textures.

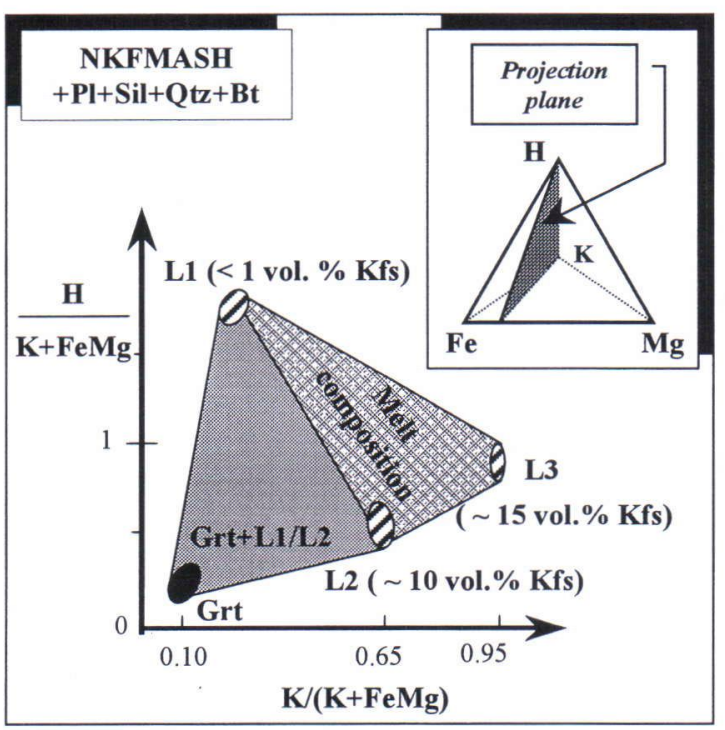

Fig. 6. Compatibility diagram in the system NKFMASH, projected from biotite, quartz, plagioclase and sillimanite, showing the relationships between garnet and melt bulk rock composition with respect to $\mathrm{aH}_{2} \mathrm{O}$. whereas L3 was formed by reaction (3). Fourthly, garnet and cordierite coronas are not in equilibrium with $\mathrm{K}$-feldspar, which is consistent with the textural observations.

The L1, L2 and L3 leucosomes are interpreted as different $\mathrm{P}-\mathrm{T}-\mathrm{aH}_{2} \mathrm{O}$ stages of progressive in situ melting of the same source. Thus the variation in potassium content in leucosomes is not related to the difference in the protolith composition, but it is probably related to changing $\mathrm{aH}_{2} \mathrm{O}$ conditions during melting. According to Patiño Douce and Harris (1998), increasing $\mathrm{aH}_{2} \mathrm{O}$ in metasedimentary rocks during melting experiments at $\mathrm{T}=$ $750^{\circ} \mathrm{C}$ and $\mathrm{P}=6 \mathrm{kbar}$ gives rise to $\mathrm{K}$-poor melts, whereas water-undersaturated melting generates K-rich melts under identical P-T conditions and bulk rock composition.

In order to check this hypothesis in the present natural system, bulk compositions of leucosomes L1, L2 and L3 as well as mineral compositions of the mesosome were projected on the same compatibility diagram (Fig. 6). In this projection, biotite is considered to be in excess instead of water $(\mathrm{H})$ and is used as a projection phase together with quartz, sillimanite and plagioclase. Therefore, NKFMASH system is reduced to $\mathrm{H}-\mathrm{K}-\mathrm{FeMg}$ and represented by the $\mathrm{H} /(\mathrm{K}+\mathrm{FeMg})$ vs. $\mathrm{K} /(\mathrm{K}+\mathrm{FeMg})$ diagram (Fig. 6). A water content of $2 \mathrm{wt} \%$, corresponding to $\mathrm{P}-\mathrm{T}$ conditions of $6 \mathrm{kbar}$ and $750^{\circ} \mathrm{C}$ according to the experimental data of Patiño Douce and Harris (1998), was used to account for the $\mathrm{H}_{2} \mathrm{O}$ released during crystallization. This projection shows, firstly, that the L1 leucosome generated by reaction (1) is projected at $\mathrm{H} /(\mathrm{K}+\mathrm{FM})$ $>1$, whereas the L2 leucosome and the cordieritebearing L3 leucosome are projected at $\mathrm{H} /(\mathrm{K}+$ $\mathrm{FM})<1$. Therefore, L1 (with 1 vol\% of Kfs) could have been formed in situ by melting reaction (1) under water-saturated conditions involving mainly plagioclase and quartz. Instead, L2 (10 vol\% Kfs) and L3 (15 vol\% Kfs) could have been formed by reactions (1) and (3), respectively, under waterundersaturated conditions by melting mainly of biotite + quartz. Secondly, the projection shows that the L1 and L2 compositions preclude equilibrium between garnet and L3 leucosome. This also suggests that the same garnet-producing 
Fig. 7. Pseudosection of Vielzeuf and Holloway (1988), P-T-X and inferred P-T-t path.

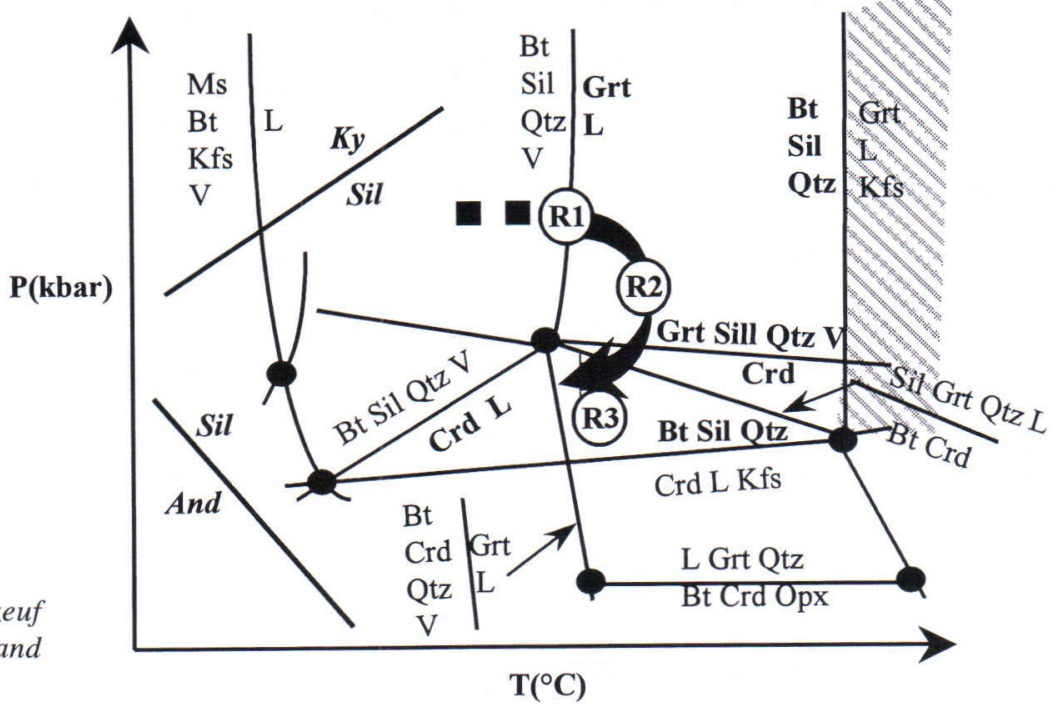

reaction (1) formed L1 and L2, whereas L3 was formed by the cordierite-producing reaction (3) during decompression.

\section{P-T path}

The bulk rock compositions of the studied migmatites are close to those of Vielzeuf and Holloway (1988). Therefore, the pseudosection for an intermediate $X_{\mathrm{Mg}}$ proposed by these authors can be used to draw the P-T path followed by the migmatites (Fig. 7). The divariant assemblages are represented by single lines for clarity. The observed textures can be explained by decompression from the peak conditions determined by melting reaction (1).

The P-T domain of the studied migmatites is located on the low-temperature side of the fluidabsent melting reaction $\mathrm{Bt}+\mathrm{Sil}+\mathrm{Qtz} \rightarrow \mathrm{Grt}+$ Liq + Kfs (Fig. 7) since no K-feldspar has been observed in equilibrium with garnet. The P-T position of this reaction is about $850^{\circ} \mathrm{C}$ at $6 \mathrm{kbar}$ (Vielzeuf \& Holloway 1988), although the temperature depends upon the occurrence and composition of plagioclase and to a lesser extent on the $\mathrm{X}_{\mathrm{Mg}}$ of the rock. The addition of $\mathrm{Na}$ into the KFMASH system shifts melting curves to lower temperatures. For common plagioclase-bearing metapelitic rocks, the above reaction is located at about $750^{\circ} \mathrm{C}$ between 6 and 10 kbar (Le Breton \& Thompson 1988).

Metamorphic cordierite is usually not stable at pressures higher than $6 \mathrm{kbar}$ in most metapelites (e.g. Aranovich \& Podlesskii 1983). Therefore, cordierite replacing garnet (reaction 2) indicates that the peak event was followed by decompression. Moreover, reaction (3) has a relatively flat slope (Vielzeuf \& Holloway 1988) at about $4 \mathrm{kbar}$ between 700 and $750^{\circ} \mathrm{C}$. Therefore, the cordierite-bearing leucosome L3 could have been formed during the decompression stage.

The P-T- $\mathrm{aH}_{2} \mathrm{O}$ conditions of the study area were constrained by combining THERMOCALC calculation (Powell \& Holland 1988, version 2.5) with classical geothermometers and available experimental data. Given the above discussion, calculations were performed at different $\mathrm{aH}_{2} \mathrm{O}$ using BtGrt-Crd-Pl-Sil/And-Kfs assemblages. The results are shown in Tables 4 and 5 and in Fig. 8.

In order to estimate the peak metamorphic conditions in the mesosome, THERMOCALC calculations were performed using core compositions of different phases, and sillimanite instead of andalusite. Calculations on average PT at different 


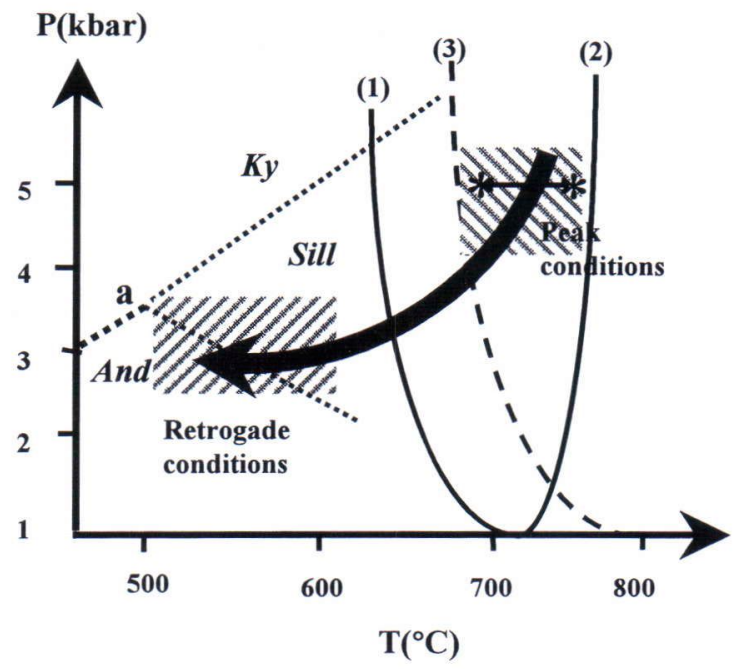

Fig. 8. THERMOCALC results for the peak and retrograde conditions. (1) metapelite-solidus and (2) $B t+$ Sill $+Q t z+P l g=G r t+K f s+L$ after Le Breton and Thompson (1988); (3) Qtz-Ab- $\mathrm{H}_{2} \mathrm{O}$ after Clemens and Vielzeuf (1987). $*--*=$ range of solidus temperatures for melting of plagioclase $\left(a n_{0}-a n_{80}\right)+$ quartz at $5 \mathrm{kbar}$ after Johannes (1978), (a) AS-triple point of Holdaway (1971).

$\mathrm{aH}_{2} \mathrm{O}$ yielded an independent set of reactions in all cases: with $\mathrm{aH}_{2} \mathrm{O}=0$ to $1, \mathrm{P}$ is $3-5.5 \mathrm{kbar}$ and $\mathrm{T}=600-800^{\circ} \mathrm{C}($ Table 4$)$.

To constrain the peak metamorphic temperature, an attempt of calculation was made on the basis of the $\mathrm{Fe}-\mathrm{Mg}$ cation exchange between core compositions of garnet and biotite using the calibrations of Ferry and Spear (1978), Hodges and Spear (1982), Perchuk and Lavrentèva (1983), and Williams and Grambling (1991). The results obtained using the formulation of Ferry and Spear (1978) and Hodges and Spear (1982) gave values in the range of $710-775^{\circ} \mathrm{C}$ at $4.5-5 \mathrm{kbar}$ whereas the formulations of Perchuk and Lavrentèva (1983) and Williams and Grambling (1991) gave lower temperatures $\left(<700^{\circ} \mathrm{C}\right.$; Table 5$)$. Temperatures lower than $700^{\circ} \mathrm{C}$ at such pressures are not, however, considered realistic. According to Chipera and Perkins (1988), the calibrations of the garnet-biotite thermometer which use solely $\mathrm{Fe}$ $\mathrm{Mg}$ partition data yield more precise results than those which incorporate the effect of other components. However, the more recent reformulation of the garnet-biotite thermometer by Bhattacharya et al. (1992) also yields temperatures lower than $700^{\circ} \mathrm{C}$. Such low values are probably the result of not taking into account the effect of $\mathrm{Ti}$ in biotite.

Based on these results and on the paragenetic analyses, we conclude that the most likely range for the peak metamorphic conditions is $700-750^{\circ} \mathrm{C}$ at 4-5 kbar, implying $\mathrm{aH}_{2} \mathrm{O}$ in the range of $0.4-$ 0.7 (Table 5). Such $\mathrm{aH}_{2} \mathrm{O}$ conditions are consistent with the recent data of Aranovich and Newton (1997). In addition, experimental data (Patiño Douce \& Harris 1998) have shown that K-poor (trondhjemitic) leucosomes can be generated by

Table 4. Average P-T calculations using THERMOCALC calculation (Powell \& Holland 1988) for the mesosome and the discordant leucosome vein (L2) assemblages.

\begin{tabular}{|c|c|c|c|c|c|c|}
\hline \multirow[t]{2}{*}{$\mathrm{aH}_{2} \mathrm{O}$} & \multicolumn{2}{|c|}{$\begin{array}{c}\text { Mesosome } \\
\text { without andalusite } \\
\text { (peak conditions) }\end{array}$} & \multicolumn{2}{|c|}{$\begin{array}{c}\text { Mesosome } \\
\text { with andalusite } \\
\text { (retrograde conditions) }\end{array}$} & \multicolumn{2}{|c|}{$\begin{array}{l}\text { Leucosome vein (L2) } \\
\text { (peak conditions) }\end{array}$} \\
\hline & Av. T $\left({ }^{\circ} \mathrm{C}\right)$ & P (kbar) & Av. T $\left({ }^{\circ} \mathrm{C}\right)$ & P (kbar) & Av.T $\left({ }^{\circ} \mathrm{C}\right)$ & Av. P (kbar) \\
\hline 1 & $799 \pm 54$ & $5.4 \pm 0.5$ & \multicolumn{2}{|c|}{ high fit } & $794 \pm 55$ & $5.5 \pm 1.5$ \\
\hline 0.9 & $784 \pm 52$ & $5.2 \pm 0.5$ & \multicolumn{2}{|c|}{ high fit } & $770 \pm 53$ & $5.4 \pm 1.5$ \\
\hline 0.8 & $771 \pm 51$ & $5.1 \pm 0.5$ & \multicolumn{2}{|c|}{ high fit } & $767 \pm 52$ & $5.2 \pm 1.5$ \\
\hline 0.7 & $756 \pm 49$ & $5.0 \pm 0.5$ & \multicolumn{2}{|c|}{ high fit } & $754 \pm 50$ & $5.1 \pm 1.5$ \\
\hline 0.6 & $743 \pm 47$ & $4.7 \pm 0.5$ & $631 \pm 23$ & $3.6 \pm 0.6$ & $741 \pm 48$ & $5.0 \pm 1.5$ \\
\hline 0.5 & $726 \pm 45$ & $4.5 \pm 0.4$ & $631 \pm 21$ & $3.5 \pm 0.6$ & $725 \pm 46$ & $4.8 \pm 1.5$ \\
\hline 0.4 & $706 \pm 43$ & $4.2 \pm 0.4$ & $629 \pm 19$ & $3.4 \pm 0.4$ & $705 \pm 44$ & $4.6 \pm 1.4$ \\
\hline 0.3 & $679 \pm 40$ & $3.9 \pm 0.4$ & $626 \pm 17$ & $3.4 \pm 0.4$ & $679 \pm 41$ & $4.4 \pm 1.4$ \\
\hline 0.2 & $642 \pm 36$ & $3.6 \pm 0.4$ & $619 \pm 17$ & $3.3 \pm 0.4$ & $644 \pm 38$ & $4.0 \pm 1.4$ \\
\hline 0.1 & $584 \pm 33$ & $3.1 \pm 0.4$ & $604 \pm 17$ & $3.3 \pm 0.4$ & $587 \pm 33$ & $3.4 \pm 1.4$ \\
\hline
\end{tabular}


Table 5. Temperature estimates at 4 and 5 kbar in the mesosome and adjacent discordant leucosome vein (L2) using Grt-Bt calibration: 1 = Ferry and Spear (1978), $2=$ Hodges and Spear (1982), 3 and $4=$ Perchuk and Lavrentèva (1983), 5 = Williams and Grambling (1991).

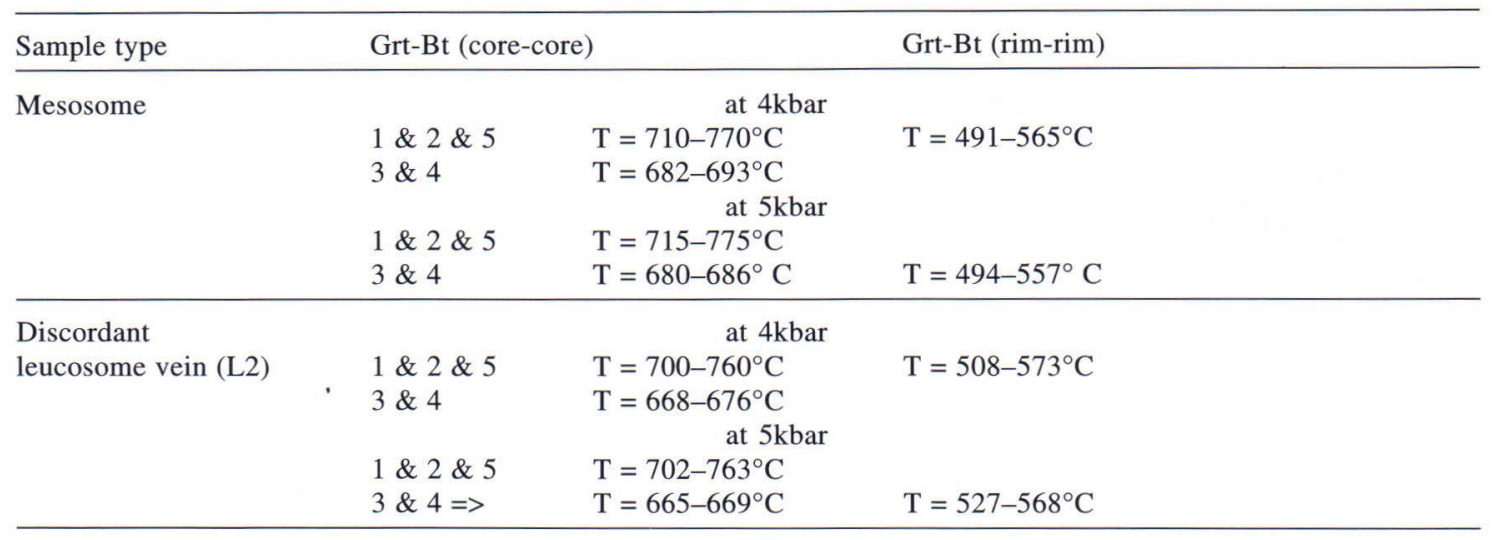

melting of metasedimentary rocks at high $\mathrm{aH}_{2} \mathrm{O}$ instead of generating K-rich (granitic) leucosomes at conditions $\left(\mathrm{P}=6 \mathrm{kbar}, \mathrm{T}=750^{\circ} \mathrm{C}\right)$ similar to the estimated peak conditions of the studied migmatites.

Using andalusite instead of sillimanite and rim compositions instead of core compositions, average PT calculations using THERMOCALC yield a complete set of independent reactions only for a domain in which $\mathrm{aH}_{2} \mathrm{O}$ is between 0.1 and 0.6. The average PT conditions are 3-3.6 $\pm 1.5 \mathrm{kbar}$ and $619-631 \pm 50^{\circ} \mathrm{C}$ (Table 4 ). These results are consistent with garnet-biotite thermometry ranging between $500-630^{\circ} \mathrm{C}$ at $3.5-4 \mathrm{kbar}$.

\section{AGE DETERMINATIONS}

The mesosome contains monazite, garnet and zircon, while the granitic leucosome vein (L-granite = sample 45) yielded only monazite. The samples used for garnet and monazite dating are of two types: i) a mesosome - L1 leucosome pair (sample 46) and ii) a mesosome - L1 leucosome - L2 leucosome triplet (sample 51) (Tables 6 and 7). The cordierite-bearing L3 leucosome was not dated by conventional methods because of its occurrence as small and rare patches makes it impossible to separate perfectly from the mesosome.
However, an attempt at age determination was made by in situ dating on one zircon grain in a polished thin section.

\section{Review of minerals used and the problem of closure temperature of garnet}

Garnet is widely distributed in metapelitic rocks, and crystallizes in response to changing PT conditions. Chemical composition (including Sm-Nd) is usually preserved intact during cooling because cation diffusion rates in garnet are very slow. The chemical composition of garnet can be used to calculate the PT conditions of its growth which, combined with age data, provides a method for determining P-T-t paths for metamorphic terrains (e.g. DeWolf et al. 1996). Diffusion rates of $\mathrm{Nd}$ in garnet remain poorly known and the empirical closure temperature for $\mathrm{Sm}-\mathrm{Nd}$ is still debated (e.g. Mezger et al. 1992, Ganguly et al. 1998).

Uncertainty about the absolute closure temperature (Tc) arises because it is known to depend on factors such as diffusion and cooling rate, grain size, crystal geometry, composition, and thermal history of the rock (e.g. Mezger et al. 1989). Low Tc $\left(<700^{\circ} \mathrm{C}\right)$ have been proposed e.g. by Mezger et al. (1992) and Burton et al. (1993) while some other authors have shown evidence of higher temperatures that could be at least $700^{\circ} \mathrm{C}$ (Hensen \& 
Zhou 1995), about $760^{\circ} \mathrm{C}$ (Vance \& O’Nions 1990 ) or more than $800^{\circ} \mathrm{C}$ (Cohen et al. 1988, Jagoutz 1988).

Depending on the closure temperature, garnet is expected to date either the peak metamorphic event or the cooling event. This most important aspect of garnet Sm-Nd studies is still debated. According to Patchett and Ruiz (1987), garnets give Sm-Nd ages that reflect cooling events, whereas Burton and O'Nions (1991) have provided examples of garnets that crystallized during the prograde stage. Thus, garnet isotopic data alone cannot discriminate between these two possibilities. For this reason, an isotopic study on monazite as well as ion probe dating on zircons were performed.

Monazite is a ubiquitous accessory mineral in metamorphic rocks with various bulk compositions and in granitic rocks (e.g. Parrish 1990, DeWolf et al. 1993, Nabelek et al. 1995). On the basis of several studies (e.g. Copeland et al. 1988, Parrish 1990), the effective closure temperature for monazite is about $720-750^{\circ} \mathrm{C}$ and an even higher value was suggested by Spear and Parrish (1996). However, the Tc of U-Pb system depends on several variables such as the presence or absence of fluid, the composition of fluid, and the strain rate during cooling (Mezger et al. 1992).

\section{Analytical methods}

Mineral separation and chemical treatment were done at the Laboratory of Mineralogy and the Laboratory of Isotope Geology of the Geological Survey of Finland, respectively. The measurements were made in a dynamic mode on a VG Sector 54 mass spectrometer using triple filaments at the Geological Survey of Finland. Care was taken in the field and laboratory in order to sample exclusively the mesosome and the different types of leucosomes. About $2 \mathrm{~kg}$ of each sample was crushed and ground. Samples were then separated on a shaking table and separation into magnetic and non-magnetic fractions was done with a Carpco magnet separator. Subsequently, garnet, monazite and zircon were separated by heavy liquids and by magnetic separation using a Frantz isodynamic separator. The final purification was achieved by handpicking under a stereomicroscope.

\section{Sm-Nd on garnet-whole rock}

Recent studies by Sm-Nd methods (e.g. DeWolf et al. 1996) have shown that the amount of Sm and $\mathrm{Nd}$ in garnet can be affected by the presence of microscopic inclusions of monazite and/or zircon. In order to avoid such contamination, leaching of garnet fractions was performed following the stepwise dissolution method of DeWolf et al. (1996). This method involves powdering of about $300 \mathrm{mg}$ of separated garnet in a boron carbide mortar for ca. 30 minutes and leaching in hot $6 \mathrm{~N} \mathrm{HCl}$ for ca. 6 hours, followed by rinsing with deionized water.

One of the most critical steps in any isotope work is the homogenisation of spike and sample. This may be a problem especially for samples rich in $\mathrm{Al}$ and cause biased $\mathrm{Sm} / \mathrm{Nd}$ ratios. In this study each garnet fraction was dissolved in two Savillex teflon beakers in order to improve the dissolution. After careful evaporation of fluorides (with $\mathrm{HClO}_{4}$ and $\mathrm{HNO}_{3}$ ) the residue was dissolved in $6 \mathrm{~N} \mathrm{HCl}$. Finally the solutions were combined and a mixed ${ }^{149} \mathrm{Sm}-{ }^{150} \mathrm{Nd}$ spike was added into a clear solution (no aliquoting). Estimated error in ${ }^{147} \mathrm{Sm} /{ }^{144} \mathrm{Nd}$ is $0.4 \%,{ }^{143} \mathrm{Nd} /{ }^{144} \mathrm{Nd}$ ratio was normalized to ${ }^{146} \mathrm{Nd} /$ ${ }^{144} \mathrm{Nd}=0.7219$ and the average value for La Jolla standard was ${ }^{143} \mathrm{Nd} /{ }^{144} \mathrm{Nd}=0.511852 \pm 12(\mathrm{SD}, \mathrm{n}=$ 20 , errors in last significant digits).

The dissolution of monazite and zircon and chemical separation of $\mathrm{U}$ and $\mathrm{Pb}$ were done following the method described by Krogh (1973).

\section{Results and interpretation}

Sm-Nd on garnet-whole rock

$\mathrm{Sm}$ and $\mathrm{Nd}$ concentrations and $\mathrm{Nd}$ isotopic ratios are given in Table 6 and plotted on a conventional isochron diagram (Fig. 9). The ${ }^{147} \mathrm{Sm} /{ }^{144} \mathrm{Nd}$ ratios in garnet from the L1 leucosome (sample 513B) are slightly lower than those in garnet from the adjacent mesosome (sample 51-1A) and the L2 leucosome (sample 51-1B). This is probably due 
Table 6. Sm-Nd data on garnet-whole rock from the mesosome and the leucosomes of the studied migmatites.

\begin{tabular}{|c|c|c|c|c|c|}
\hline Sample & $\begin{array}{c}\mathrm{Sm} \\
(\mathrm{ppm})\end{array}$ & $\begin{array}{c}\mathrm{Nd} \\
(\mathrm{ppm})\end{array}$ & ${ }^{147} \mathrm{Sm} /{ }^{144} \mathrm{Nd}$ & ${ }^{43} \mathrm{Nd} /{ }^{144} \mathrm{Nd}$ & $\pm 2 \sigma \varepsilon_{\mathrm{Nd}}(1900) \mathrm{T}($ grt-wr) (Ma) \\
\hline
\end{tabular}

Sample 46A-B: mesosome-L1 pair $46 \mathrm{~B}=$ mesosome

Whole-Rock

$\begin{array}{lcclll}6.29 & 38.79 & 0.0980 & 0.511382 \pm 11 & -0.5 & \\ 0.773 & 0.481 & 0.9744 & 0.522300 \pm 230 & & 1893 \pm 40\end{array}$

$46 \mathrm{~A}=$ leucosome L1

Whole-Rock

$0.6 \quad 0.5146$

$0.516463 \pm 26$ $1871 \pm 14$

Sample 51A-B: Mesosome-L1-L2 triplet 51-1A = mesosome

\begin{tabular}{|c|c|c|c|c|c|c|}
\hline Whole-Rock & 3.83 & 23.25 & 0.0997 & $0.511408 \pm 12$ & \multirow[t]{2}{*}{-0.4} & \\
\hline Garnet & 0.10 & 0.093 & 0.6822 & $0.518603 \pm 60$ & & $1877 \pm 18$ \\
\hline \multicolumn{7}{|c|}{$51-3 \mathrm{~B}=$ leucosome L1 } \\
\hline Whole-Rock & 5.55 & 31.90 & 0.1051 & $0.511450 \pm 10$ & \multirow[t]{2}{*}{-0.9} & \\
\hline Garnet & 1.32 & 2.25 & 0.3551 & $0.514543 \pm 32$ & & $1880 \pm 23$ \\
\hline \multicolumn{7}{|c|}{$51-1 B=$ leucosome L2 } \\
\hline Whole-Rock & 7.65 & 37.49 & 0.1233 & $0.511663 \pm 10$ & \multirow[t]{2}{*}{-1.2} & \\
\hline Garnet & 0.85 & 0.62 & 0.8220 & $0.520134 \pm 33$ & & $1843 \pm 11$ \\
\hline
\end{tabular}

Fig. 9. Sm-Nd isochron diagram with analyses of garnet (grt) and whole rocks (WR) from leucosomes and mesosome.

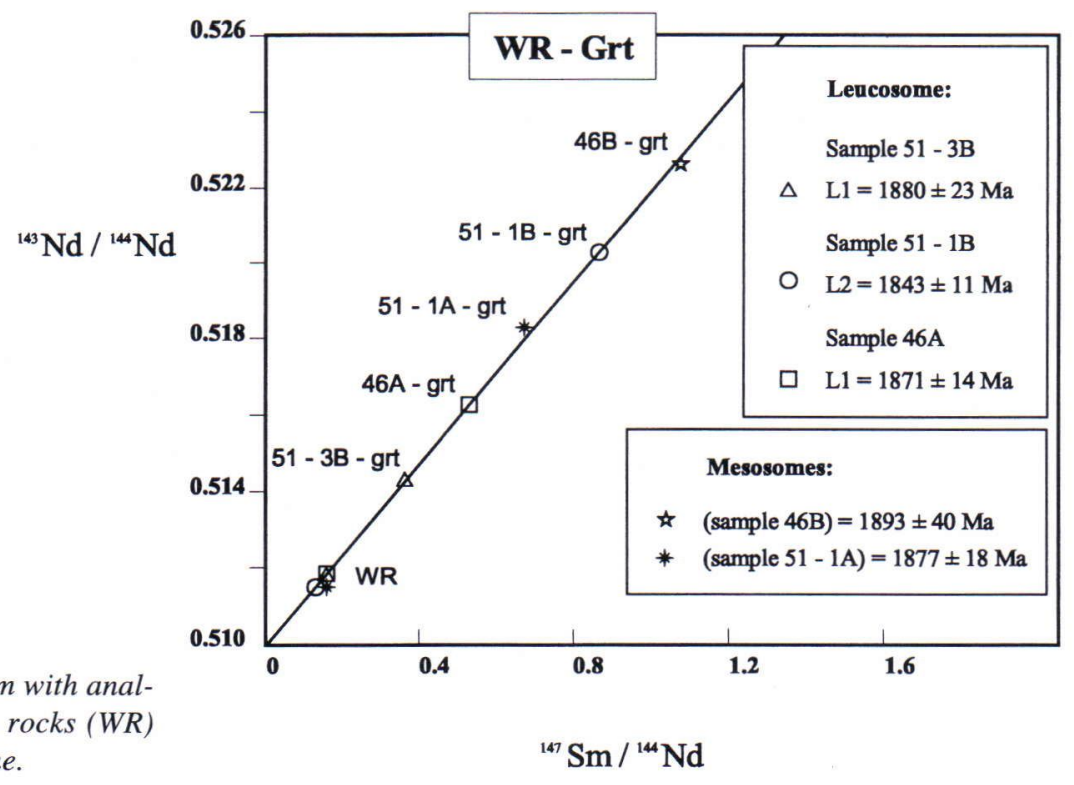

garnet has a high ${ }^{147} \mathrm{Sm} /{ }^{144} \mathrm{Nd}$ ratio. Also the $\mathrm{Sm}$ and $\mathrm{Nd}$ concentrations are much higher in unleached garnet. The absolute garnet ages vary from $1843 \pm 11$ to $1893 \pm 40$ Ma (Table 6 ). The data indicate, however, that two marginally different age to the persistence of monazite inclusions in spite of leaching as also the $\mathrm{Sm}$ and $\mathrm{Nd}$ concentrations are slightly elevated. The ${ }^{147} \mathrm{Sm} /{ }^{144} \mathrm{Nd}$ ratio of the unleached fraction is not considerably different from that of the whole rock, whereas the leached 
groups may be present: 1) The pairs mesosome L1 leucosome (samples 51-1A/51-3B and 46A/ $46 \mathrm{~B})$ have ages ranging between $1871 \pm 14$ and $1893 \pm 40 \mathrm{Ma}$ (average $1880 \mathrm{Ma}$ ). 2) The L2 leucosome (sample 51-1B) has an age of $1843 \pm 11 \mathrm{Ma}$ that is marginally younger than the age of the mesosome - L1 leucosome pairs. Numerical analysis of the two age groups suggest that they are statistically different, but caution must be exercised in interpreting the geological significance of this result, especially when the younger group is defined by one analysis only.

If the Tc of Sm-Nd system is higher than $800^{\circ} \mathrm{C}$, as it was suggested by Cohen et al. (1988) and Jagoutz (1988), the group with average Sm$\mathrm{Nd}$ age of $1880 \mathrm{Ma}$ could reflect the peak metamorphic event age since the Tc is higher than the estimated peak conditions $\left(700-750^{\circ} \mathrm{C}\right)$ in the studied migmatites. In contrast, the Sm-Nd age of $1843 \pm 11$ Ma obtained for the L2 leucosome vein could be an artefact either due to the small size and scarcity of garnet or due to Sm-Nd fractionation resulting from garnet dissolution during leaching. Therefore, the difference in age between the mesosome and L2 leucosome may not be real.

\section{$U-P b$ on monazite}

In all samples, the monazites from leucosomes have higher $U$ contents than those in the meso- some. This is true especially in the L-granite (sample 45) in which the content reaches 16900 ppm (Table 7). Monazites from the mesosome and leucosomes are nearly concordant and yield an average age of $1878.5 \pm 1.5 \mathrm{Ma}$ (Table 7, Fig. 10). This result agrees within error with the age of the group that has the average Sm-Nd age of $1880 \mathrm{Ma}$. On the basis of microscopic observations, monazites often occur in association with biotite-sillimanite assemblage in the main foliation plane and as inclusions in garnets and, therefore, they grew before or at the same time as the garnets formed by reaction (1) at peak conditions. The monazite ages thus mark the peak metamorphic stage rather than a cooling event. Therefore, Tc for the monazites is slightly higher than the peak metamorphic conditions of $700-750^{\circ} \mathrm{C}$ reached by the migmatites (cf. Spear \& Parrish 1996). This is consistent with the previous studies which show that monazite may preserve ages corresponding to peak temperatures up to granulite facies conditions (DeWolf et al. 1993), and may record prograde growth ages (Vry et al. 1996).

The fact that no difference in age is observed between leucosomes L1, L2 and L-granite could indicate that L1 and L2 were effectively formed during the same low-pressure, high-temperature event by in situ melting processes, while L-granite was injected into the system during the peak metamorphic event.

Table 7. U-Pb data on monazite from the mesosome and the leucosomes of the studied migmatites.

\begin{tabular}{|c|c|c|c|c|c|c|c|c|c|c|}
\hline \multirow[t]{2}{*}{ Sample } & \multirow[b]{2}{*}{$\begin{array}{c}\text { wt } \\
(\mathrm{mg})\end{array}$} & \multirow[b]{2}{*}{$\begin{array}{c}\mathrm{U} \\
(\mathrm{ppm})\end{array}$} & \multirow[b]{2}{*}{$\begin{array}{c}\mathrm{Pb} \\
(\mathrm{ppm})\end{array}$} & \multirow{2}{*}{$\begin{array}{c}\text { Measured } \\
{ }^{206} \mathrm{~Pb} / \\
{ }^{204} \mathrm{~Pb}\end{array}$} & \multirow{2}{*}{$\begin{array}{c}{ }^{1)} \\
{ }^{208} \mathrm{~Pb} / \\
{ }^{206} \mathrm{~Pb}\end{array}$} & \multirow{2}{*}{$\begin{array}{c}\text { 1) } \\
{ }^{206} \mathrm{~Pb} / \\
{ }^{238} \mathrm{U}\end{array}$} & \multirow{2}{*}{$\begin{array}{c}{ }^{1)} \\
{ }^{207} \mathrm{~Pb} / \\
{ }^{235} \mathrm{U}\end{array}$} & \multicolumn{2}{|c|}{ Age (Ma) } & \multirow[b]{2}{*}{$\begin{array}{l}{ }^{207} \mathrm{~Pb} / \\
{ }^{206} \mathrm{~Pb}\end{array}$} \\
\hline & & & & & & & & $\begin{array}{c}{ }^{206} \mathrm{~Pb} / \\
{ }^{238} \mathrm{U}\end{array}$ & $\begin{array}{l}{ }^{207} \mathrm{~Pb} / \\
{ }^{235} \mathrm{U}\end{array}$ & \\
\hline \multicolumn{11}{|l|}{ Mesosome-LI pair } \\
\hline $46 \mathrm{~B}=$ mesosome & 1.2 & 3600 & 4323 & 87106 & 3.0 & 0.33973 & 5.3822 & 1885 & 1882 & 1878 \\
\hline $46 \mathrm{~A}=\mathrm{L} 1$ & 0.9 & 4720 & 5021 & 93335 & 2.5 & 0.34033 & 5.3931 & 1888 & 1884 & 1879 \\
\hline \multicolumn{11}{|c|}{ Mesosome-L1-L2 triplet } \\
\hline $51-1 \mathrm{~A}=$ mesosome & 1.4 & 4752 & 4303 & 67232 & 2.0 & 0.33830 & 5.3602 & 1879 & 1879 & 1879 \\
\hline $51-3 \mathrm{~B}=\mathrm{L} 1$ & 1.2 & 4984 & 4545 & 28540 & 2.0 & 0.33704 & 5.33512 & 1872 & 1874 & 1877 \\
\hline $51-1 B=L 2$ & 1.8 & 6718 & 5915 & 27165 & 1.9 & 0.34332 & 5.4381 & 1903 & 1891 & 1878 \\
\hline \multicolumn{11}{|l|}{ L-granite } \\
\hline 45 & 2.5 & $1.69 \%$ & $1.11 \%$ & 295146 & 1.1 & 0.34596 & 5.4818 & 1915 & 1898 & 1879 \\
\hline
\end{tabular}

1) Corrected for mass fractionation (0.1\%/a.m.u.), blank (0.2 ng Pb) and common lead (Stacey \& Kramers 1975) $2 \sigma$-error estimates are $1.5 \%$ for $\mathrm{Pb} / \mathrm{U}$ ratio in monazite. 


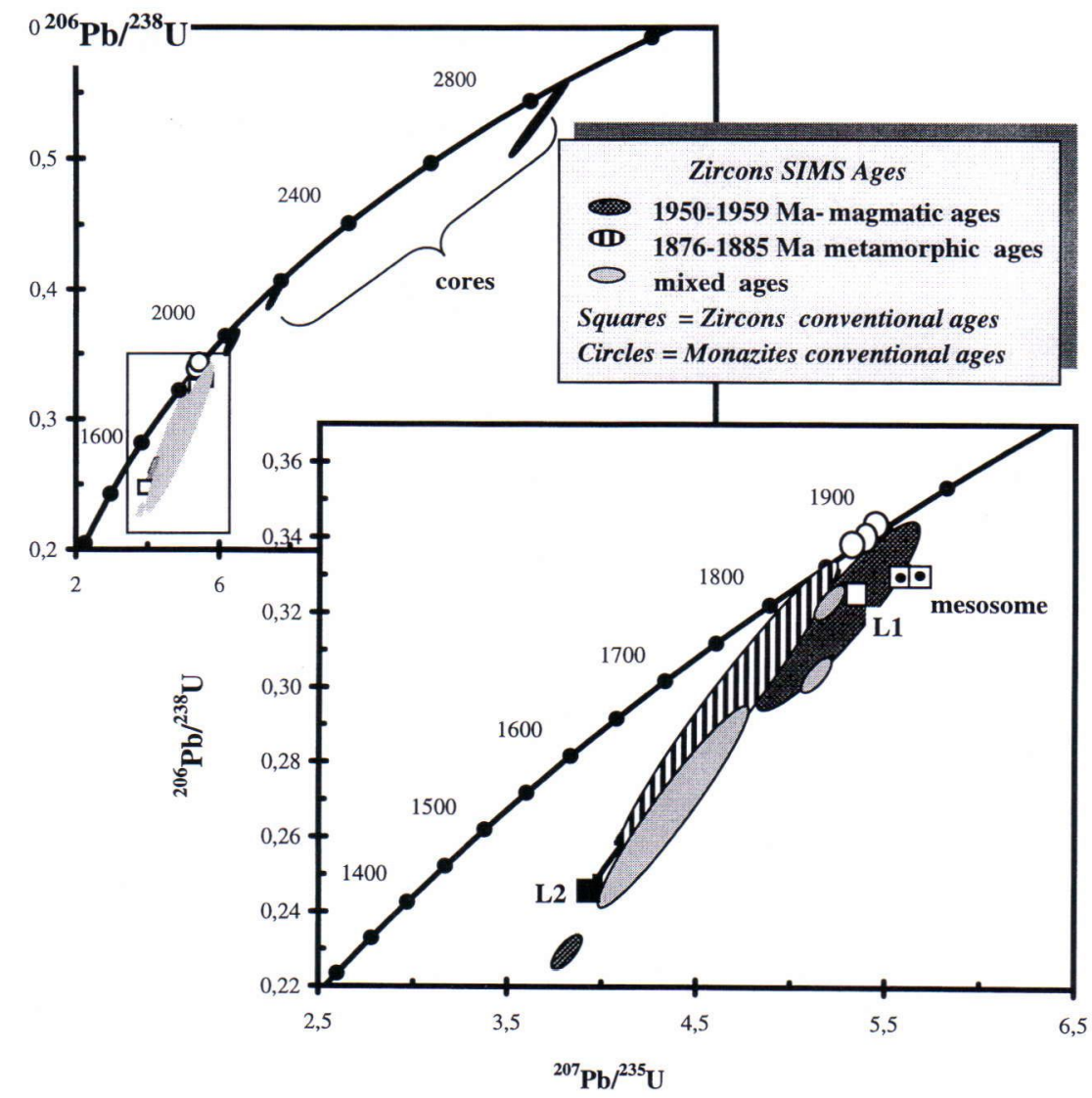

Figure 10. Concordia plot of ion probe and conventional analyses on zircons and conventional analyses on monazites. The inset shows an enlargement of the lower part of the concordia; note that the zircon ages by conventional method (squares) are more discordant than the monazite ages (circles) and are plotted in the same area as the zircon ages from rims by ion probe. $L 1=$ layered leucosome, $L 2=$ discordant leucosome. The inset also shows that the mixed and magmatic ion probe ages are slightly more discordant than the metamorphic rim ages.

\section{$U-P b$ on zircon}

The results of conventional U-Pb zircon analyses are listed in Table 8 and illustrated in Fig. 10 together with monazite using the program ISOPLOT/Ex-1.00 (Ludwig 1998). The zircons are slightly discordant and give ${ }^{207} \mathrm{~Pb} /{ }^{206} \mathrm{~Pb}$ ages of 1992-2011 Ma in the mesosome, $1950 \mathrm{Ma}$ in the L1 leucosome and $1892 \mathrm{Ma}$ in the L2 leucosome. The latter is more discordant than the other analyses. There are three possible explanations for the discordance: i) large lead loss during a metamorphic event (e.g. Holmes 1954), ii) mixed age populations (e.g. Gebauer \& Grünenfelder 1979), and iii) composite grains with several growth zones (e.g. Kinney et al. 1988). In the studied migmatites, the ages obtained from the mesosome are within the range found in Svecofennian metasediments which have been usually interpreted as a mixture of Proterozoic and Archaean sources (Huhma et al. 1991, Claesson et al. 1993). However, if compared with the average ${ }^{207} \mathrm{~Pb} /{ }^{206} \mathrm{~Pb}$ ages of the supposed sedimentary rocks which did not undergo anatexis, the L2 leucosome dated at 1892 $\mathrm{Ma}$ is slightly younger. This is most likely due to a large lead loss during the peak metamorphic event dated at $1878 \mathrm{Ma}$ by Sm-Nd and U-Pb methods on garnet and monazite, respectively. 
Table 8. U-Pb conventional data on zircon.

\begin{tabular}{|c|c|c|c|c|c|c|c|c|c|c|}
\hline \multirow[b]{2}{*}{ Sample } & \multirow[b]{2}{*}{$\begin{array}{c}\mathrm{wt} \\
(\mathrm{mg})\end{array}$} & \multirow[b]{2}{*}{$\begin{array}{c}\mathbf{U} \\
(\mathrm{ppm})\end{array}$} & \multirow[b]{2}{*}{$\begin{array}{c}\mathrm{Pb} \\
(\mathrm{ppm})\end{array}$} & \multirow{2}{*}{$\begin{array}{c}\text { Measured } \\
{ }^{206} \mathrm{~Pb} / \\
{ }^{204} \mathrm{~Pb}\end{array}$} & \multirow{2}{*}{$\begin{array}{c}\text { 1) } \\
{ }^{208} \mathrm{~Pb} / \\
{ }^{206} \mathrm{~Pb}\end{array}$} & \multirow{2}{*}{$\begin{array}{l}\text { 1) } \\
{ }^{206} \mathrm{~Pb} / \\
{ }^{238} \mathrm{U}\end{array}$} & \multirow{2}{*}{$\begin{array}{c}\text { 1) } \\
{ }^{207} \mathrm{~Pb} / \\
{ }^{235} \mathrm{U}\end{array}$} & \multicolumn{2}{|c|}{ Age (Ma) } & \multirow[b]{2}{*}{$\begin{array}{l}{ }^{207} \mathrm{~Pb} / \\
{ }^{206} \mathrm{~Pb}\end{array}$} \\
\hline & & & & & & & & $\begin{array}{c}{ }^{206} \mathrm{~Pb} / \\
{ }^{238} \mathrm{U}\end{array}$ & $\begin{array}{c}{ }^{207} \mathrm{~Pb} / \\
{ }^{235} \mathrm{U}\end{array}$ & \\
\hline 46A (leucosome L1) & 2.6 & 603 & 200 & 10190 & .06 & .3252 & 5.3637 & 1815 & 1879 & 1950 \\
\hline 46B (mesosom & 2.6 & 535 & 198 & 10785 & .17 & .33047 & 5.5773 & 1841 & 1913 & 1992 \\
\hline $51-1 \mathrm{~A}(\mathrm{me}$ & 6.3 & 586 & 210 & 2413 & .11 & .32999 & 5.6315 & 1838 & 1921 & 2011 \\
\hline 51-1B (leucosome L2) & 6.7 & 1252 & 336 & 640 & .04 & .24743 & 3.9502 & 1425 & 1624 & 1892 \\
\hline
\end{tabular}

1) Corrected for mass fractionation (0.1\%/a.m.u.), blank (0.2 ng Pb) and common lead (Stacey \& Kramers 1975). $2 \sigma$-error estimates are $0.1 \%$ for the ${ }^{207} \mathrm{~Pb} /{ }^{206} \mathrm{~Pb}$ ratio and $0.7 \%$ for $\mathrm{Pb} / \mathrm{U}$ ratio in zircon.

\section{Zircon structures revealed by CL-imaging}

Handpicked zircon grains as well as a fragment of a polished thin section containing zircon were mounted in epoxy with the reference standard, polished and coated with ca. $30 \mathrm{~nm}$ of gold for ion microprobe dating. In order to avoid overlapping of two or more distinct growth zones during analysis by ion microprobe, the grains were studied by cathodoluminescence imaging (CL). This technique shows the internal structure of grains and allows one to minimize the number of ion microprobe analyses.

CL-imaging revealed complex zoning structures within the zircon grains in all the samples (Figs. 11 a-1). Some grains with rounded to subrounded form display a distinct core which appears in some zircons as a fragment of an original grain overgrown by one or two thin outer rims. This suggests a complicated growth history and more than one episode of zircon crystallization. The rims are characterized by two kinds of structures: i) welldeveloped unzoned overgrowths about 10 to 25 $\mu \mathrm{mm}$ thick on an older broken oscillatory zoning that displays a sharp contact against the core (Figs. 11 a-e, h, i), and ii) weakly oscillatory zoned rims which are overgrown mostly by a very thin outer rim $(<10 \mu \mathrm{mm}$ thick) (Figs. $11 \mathrm{f}-1)$. The zoning within these rims reflects the shape of the cores and no major structural break is visible between the central and outer parts of the crystals (Figs. $11 \mathrm{~g}, \mathrm{k}, 1)$. No systematic difference in form is observed between the zircons from the samples of the mesosome and L1, L2 and L3 leucosomes.

\section{SIMS ion probe dating}

Selected domains of zircon crystals were analysed for $\mathrm{U}, \mathrm{Pb}$ and $\mathrm{Th}$ isotopic composition using a CAMECA SIMS 1270 ion microprobe at the Swedish Museum of Natural History, Stockholm. The operating techniques are described by Whitehouse et al. (1997). The ages reported here (Table 9) are based on ${ }^{207} \mathrm{~Pb} /{ }^{206} \mathrm{~Pb}$ as this ratio is more sensitive than ${ }^{206} \mathrm{~Pb} /{ }^{238} \mathrm{U}$ ratio for old ages.

The total of analyses is 18 points representing four samples (mesosome, layered leucosome L1, discordant leucosome vein L2 and cordierite-bearing leucosome L3). Although the number of analyses performed on single zircons is low, the selected grains and the domains within these grains, based on their internal structure revealed by CL-

Fig. 11. BS and CL images of single and in situ zircon grains analysed by ion probe showing the ages and the positions of analysed points. (a) and (b) are zircons from the mesosome, (c) and (d) from leucosome L1, and (e) from leucosome L2. These grains show unzoned metamorphic rims around fragments of oscillatory zoned old cores, note the sharp contact between the rim and the core in each grain. The rims of these grains give ages of between 1872-1886 Ma. $(f),(g)$ and $(k)$ are from leucosome L1 and (j) from leucosome L2. These grains show a thin unzoned rim of metamorphic origin around an oscillatory zoned rim of magmatic origin. (h) and (i) are BS and CL images, respectively, of in situ zircon from $L 3$ leucosome showing a well-developed rim around an oscillatory zoned core. (l) shows a rim with weak oscillatory zoning around a zoned core, note the continuity between the core and the rim. 

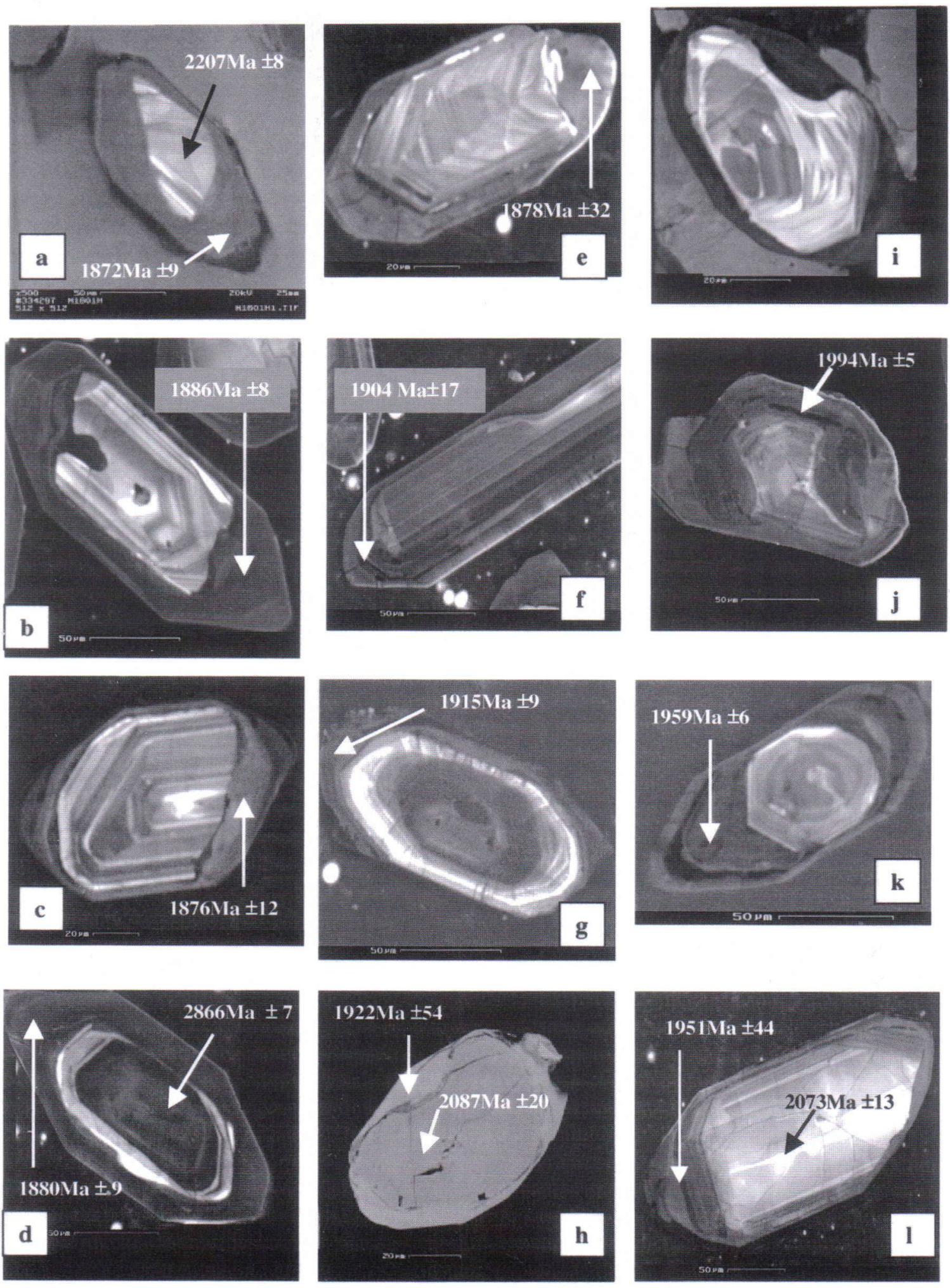
Table 9. U-Th-Pb analytical data on zircons and derived ages.

\begin{tabular}{|c|c|c|c|c|c|c|c|c|c|c|c|}
\hline \multirow[b]{2}{*}{$\begin{array}{l}\text { Sample/ } \\
\text { spot \# }\end{array}$} & \multirow[b]{2}{*}{$\begin{array}{l}\text { sample } \\
\text { type }\end{array}$} & \multirow[b]{2}{*}{$\begin{array}{l}\text { spot } \\
\text { position }\end{array}$} & \multicolumn{4}{|c|}{ derived ages (Ma) } & \multicolumn{5}{|c|}{ elemental data } \\
\hline & & & $\begin{array}{l}{ }^{207} \mathrm{~Pb} \\
{ }^{206} \mathrm{~Pb}\end{array}$ & $\pm \sigma$ & $\begin{array}{l}{ }^{207} \mathrm{~Pb} \\
{ }^{235} \mathrm{U}\end{array}$ & $\pm \sigma$ & $\begin{array}{l}{[\mathrm{U}]} \\
\mathrm{ppm}\end{array}$ & $\begin{array}{l}{[\mathrm{Pb}]} \\
\mathrm{ppm}\end{array}$ & $\begin{array}{l}\text { [Th] } \\
\text { ppm }\end{array}$ & $\begin{array}{l}\mathrm{Th} / \mathrm{U} \\
\text { calc. }\end{array}$ & $\begin{array}{l}\mathrm{Th} / \mathrm{U} \\
\text { meas. }\end{array}$ \\
\hline $\mathrm{n} 160-1 \mathrm{~b}$ & M & core & 2207 & 8 & 2184 & 23 & 190 & 102 & 127 & 0.706 & 0.666 \\
\hline $\mathrm{n} 160-5 \mathrm{~b}$ & L1 & core & 2866 & 7 & 2815 & 41 & 482 & 331 & 131 & 0.245 & 0.272 \\
\hline n160-10 & L1 & core & 2002 & 6 & 1914 & 19 & 529 & 208 & 89 & 0.157 & 0.169 \\
\hline $\mathrm{n} 160-9 \mathrm{~b}$ & L2 & core & 2073 & 13 & 2024 & 19 & 108 & 51 & 63 & 0.591 & 0.581 \\
\hline n182-01a & L3 & core & 2087 & 20 & 1979 & 15 & 569 & 265 & 91 & 0.101 & 0.161 \\
\hline n160-1a & M & rim & 1872 & 9 & 1667 & 14 & 1426 & 433 & 22 & 0.004 & 0.016 \\
\hline n160-12 & $\mathrm{M}$ & rim & 1886 & 8 & 1676 & 9 & 1648 & 524 & 223 & 0.107 & 0.135 \\
\hline $\mathrm{n} 160-2 \mathrm{a}$ & M & rim & 1907 & 8 & 1749 & 10 & 1058 & 351 & 38 & 0.017 & 0.036 \\
\hline n160-5a & L1 & rim & 1880 & 9 & 1729 & 24 & 695 & 223 & 8 & -0.002 & 0.012 \\
\hline n160-11 & L1 & rim & 1915 & 9 & 1859 & 11 & 1234 & 457 & 31 & 0.013 & 0.025 \\
\hline $\mathrm{n} 160-7 \mathrm{a}$ & L1 & rim & 1876 & 12 & 1814 & 39 & 846 & 309 & 138 & 0.120 & 0.163 \\
\hline n160-6a & L1 & rim & 1904 & 17 & 1733 & 28 & 863 & 281 & 119 & 0.115 & 0.138 \\
\hline $\mathrm{n} 160-3 \mathrm{a}$ & L1 & rim & 1959 & 6 & 1596 & 11 & 2150 & 560 & 96 & 0.011 & 0.045 \\
\hline $\mathrm{n} 160-4 \mathrm{a}$ & L1 & rim & 1994 & 5 & 1843 & 10 & 991 & 365 & 222 & 0.173 & 0.224 \\
\hline $\mathrm{n} 160-8 \mathrm{a}$ & L2 & rim & 1878 & 32 & 1768 & 23 & 411 & 161 & 80 & 0.132 & 0.194 \\
\hline n160-13 & L2 & rim & 1912 & 14 & 1702 & 24 & 434 & 142 & 145 & 0.260 & 0.335 \\
\hline $\mathrm{n} 160-9 \mathrm{a}$ & L2 & rim & 1951 & 44 & 1864 & 59 & 933 & 346 & 143 & 0.128 & 0.153 \\
\hline n182-03a & L3 & rim & 1922 & 54 & 1668 & 35 & 379 & 124 & 89 & 0.141 & 0.235 \\
\hline
\end{tabular}

$\mathrm{M}=$ mesosome

$\mathrm{L} 1=$ layered leucosome

L2= discordant leucosome vein

L3 = Crd-bearing leucosome (in situ analyses)

imaging, are considered representative enough to constrain the time of migmatization events.

\section{Concentrations of $U$ and $T h$}

The isotopic compositions of core-rim pairs of four zircon grains and separate rims of nine grains from different parts of the migmatites are presented in Table 9. The diversity in types and styles of zoning displayed by the zircon grains corresponds to the diversity in composition. The most striking chemical difference between the core and rim of each analysed grain is in the content of $U$ and Th (Table 9 and Fig. 11). The U content is higher and varies more in the zoned and unzoned rims than in the core of the same grain, except for the in situ zircon in polished thin section from L3 leucosome (Table 9, analyses 182-01a and 03a), which shows a reverse correlation. The Th content varies in accordance with the internal structure of the rims. The unzoned overgrowth is characterized by lower Th content than the core in the same grain (Table 9, analyses $160-1 \mathrm{a}$ and $\mathrm{b}$, and 160-5a and b). Instead, the weakly oscillatory zoned grains (Table 9, analyses 160-9a and b, Fig. 11i) show a reverse correlation and have higher Th contents than the unzoned overgrowths. Low-Th and high-U rims are often considered to be diagnostic of metamorphic overgrowths (e.g. Jacobs et al. 1998), while high Th contents have been noticed in zircons of magmatic origin (e.g. Pidgeon \& Wilde 1998). Therefore, this feature could be interpreted to indicate a magmatic event with later stages characterized by higher concentration of Th in the melt.

\section{${ }^{207} \mathrm{~Pb}{ }^{206} \mathrm{~Pb}$ ages and concordia plot}

The ion microprobe data of the zircons are plotted together with the conventional U-Pb zircon and monazite analyses on the concordia diagram in Fig. 10. The data obtained from the cores are slightly discordant probably because of the presence of inherited radiogenic $\mathrm{Pb}$ which is a com- 
monly reported feature (e.g. Pidgeon \& Aftalion 1978). This indicates i) that it is possible for zircons to remain undissolved in crustal melts (Watson \& Harrison 1983), and ii) that at temperatures attained by crustal melts $\left(700-900^{\circ} \mathrm{C}\right)$ diffusion of $\mathrm{Pb}$ in zircon is very slow (e.g. Paterson et al. 1992). The cores yield high ages of between $2002 \pm 12$ and $2866 \pm 14 \mathrm{Ma}$, with the oldest age detected in zircon from the L1 leucosome. These data are interpreted as the age of the detrital zircon of the protolith. The wide variation in the ages of the cores indicates heterogeneous sources of the detrital zircons (e.g. Williams et al. 1988, Chen \& Williams 1990).

The analyses on zircon rims from all the samples show a complex scatter in Fig. 10. The rims yield overlapping data points, which are slightly more discordant than the cores showing evidence of $\mathrm{Pb}$ loss. The ${ }^{207} \mathrm{~Pb} /{ }^{206} \mathrm{~Pb}$ ages are variable and three groups may be present because a) zircon rims record two geological events in accordance with the internal structure of the grains and $b$ ) ion microprobe beam straddles a boundary between two zones of different ages.

A ${ }^{207} \mathrm{~Pb} /{ }^{206} \mathrm{~Pb}$ age group of $1872-1886 \mathrm{Ma}$ is obtained from the unzoned distinct rim overgrowths on older broken oscillatory zoned grains (Figs. 11 a-e). These rims are interpreted as growth of new zircon during a metamorphic event (e.g. Hanchar \& Miller 1993, Hanchar \& Rudnick 1995). Therefore, this age group could represent a metamorphic event and explain the youngest and discordant age obtained from the L2 leucosome by conventional method on zircon. No difference in age was noticed between the unzoned rim overgrowths from different leucosomes and mesosome because all the analyses are coeval within the limits of error. This suggests a rapid growth of metamorphic zircon within the different parts of the migmatites. The data are consistent with the Sm$\mathrm{Nd}$ dating on garnet and $\mathrm{U}-\mathrm{Pb}$ dating on monazite and correspond to the oldest metamorphic event in the Tonalite-Trondhjemite Migmatite Belt.

${ }^{207} \mathrm{~Pb} /{ }^{206} \mathrm{~Pb}$ ages of $1959 \pm 12$ and $1951 \pm 88 \mathrm{Ma}$ are obtained from two zircon rims with weak oscillatory zoning from the L1 layered leucosome and the L2 discordant leucosome (Figs. $11 \mathrm{k}$ and 1 , respectively). Oscillatory zoning is interpreted as a feature of magmatic zircon rather than as an indication of growth during metamorphism (e.g. Pidgeon 1992, Hanchar \& Miller 1993, Vavra et al. 1996, Poller et al. 1997). Magmatic rocks of this age have not been encountered in the studied migmatite belt, but similar ages $(1960 \pm 12$ and $1953 \pm 2 \mathrm{Ma}$ ) are known in ophiolites occurring in the Palaeoproterozoic cover on the Archaean in eastern Finland (Fig. 1) (Peltonen et al. 1996). Also, the 1954 Ma old Knaften granite has been detected within the Svecofennian domain in northern Sweden (Wasström 1993). It might be possible that the ages of 1959-1951 Ma from the Tonalite-Trondhjemite Migmatite Belt record a real magmatic event indicating a rifting stage of the Svecofennian protocrust slightly earlier than presented by Lahtinen (1994).

The heterogeneous ${ }^{207} \mathrm{~Pb} /{ }^{206} \mathrm{~Pb}$ age group between $1904 \pm 34$ and $1994 \pm 10 \mathrm{Ma}$ (Table 9) is obtained probably because the ion probe beam straddled a zone boundary between two thin domains of different ages. The complex and asymmetrical zoning of the grains (Figs. $11 \mathrm{f}-\mathrm{j}$ ), the narrow width of the rims $(<20 \mathrm{~mm})$ and the problem of not seeing a clear image of the in situ zircon in thin section, make it difficult to locate the ion probe beam. Therefore, we suggest that the oldest age of $1994 \pm 10$ Ma could be a mixture of Archaean zircon in the core and Palaeoproterozoic zircon in the rim (analysis 160-4a, Fig. 11j). The ${ }^{207} \mathrm{~Pb} /{ }^{206} \mathrm{~Pb}$ ages of $1904 \pm 34,1915 \pm 18$ and $1922 \pm 108$ Ma from L1, L2 and L3, respectively (Figs. $11 \mathrm{f}-\mathrm{i}$ ), could be interpreted as a mixture of an outer thin metamorphic overgrowth (1872$1886 \mathrm{Ma})$ and an intermediate rim of magmatic origin (1951-1959 Ma). In comparison with these results, the 1950-1992 Ma ages yielded by conventional method (Table 8) are explicable as mixtures of the domains revealed by ion microprobe and CL-images.

\section{DISCUSSION}

\section{P-T-t evolution and melting processes}

The P-T conditions yielded by combining THER- 
MOCALC calculations, conventional geothermometry and experimental data agree with the metamorphic conditions and the P-T path deduced from the paragenetic analyses. The absence of early muscovite suggests that the stability field of muscovite + quartz has been exceeded. The P-T diagrams (Figs. 7 and 8) show that the peak metamorphic conditions were within the stability field of sillimanite and above the $\mathrm{H}_{2} \mathrm{O}$-saturated pelite solidus (reaction curve 1 in Fig. 8). This field is located within the range of solidus temperatures for melting of plagioclase + quartz at 5 kbar (Johannes 1978). Thus metamorphism of the migmatites took place at temperatures of $700-750^{\circ} \mathrm{C}$, pressures of 4-5 kbar and $\mathrm{aH}_{2} \mathrm{O}$ of $0.4-0.5$. The formation of cordierite coronas around garnet and the late crystallization of andalusite suggest that the final stage of the P-T history was characterized by decompression and cooling to the andalusite stability field at $500-650^{\circ} \mathrm{C}$ and $3-4 \mathrm{kbar}$.

The temperatures at which dehydration melting starts are widely scattered because melting of rocks may involve many phases and the effect of the simultaneous presence of more than one component is difficult to assess. The situation is made more complex by the absence or presence of fluid, its nature and the effect of $\mathrm{fO}_{2}$. On the other hand, melt compositions are mainly controlled by source composition (e.g. Patiño Douce \& Beard 1995, Korsman et al. 1999). However, Patiño Douce and Harris (1998) have shown that changes in conditions of melting may have effects on melt composition that are comparable in magnitude to the effects of changing source composition. For example, depletion in potassium content of leucosomes reflects the preferential destabilization of plagioclase relative to mica with increasing activity of $\mathrm{H}_{2} \mathrm{O}$ (e.g. Whitney \& Irving 1994, Patiño Douce \& Harris 1998). As a consequence, the residue is rich in mica and quartz but depleted in plagioclase, a feature observed in the migmatites studied here.

The genesis of the different generations of leucosomes can be interpreted in relation to in situ melting equilibria crossed during different stages of the P-T- $\mathrm{aH}_{2} \mathrm{O}$ evolution. The L1 leucosome with less than 1 vol\% of $\mathrm{K}$-feldspar and the L2 leucosome with about $10 \mathrm{vol} \%$ of $\mathrm{K}$-feldspar are interpreted to have been formed under the same $\mathrm{P}-\mathrm{T}$ conditions close to the thermal peak but at different $\mathrm{aH}_{2} \mathrm{O}$ conditions. The layered leucosome L1 probably formed at higher $\mathrm{aH}_{2} \mathrm{O}$ conditions than the discordant leucosome L2. In contrast, the cordierite-bearing L3 leucosomes with a relatively high proportion of K-feldspar (15 vol\%) are interpreted to have formed during the decompression stage at relatively low $\mathrm{aH}_{2} \mathrm{O}$. The origin of the leucosome vein L-granite remains obscure. On the basis of phase relationships and field observations, this leucosome is more likely an injection from an external source at peak metamorphic conditions than a result of in situ melting.

\section{Timing}

Isotopic dating on garnet-whole rock and monazite as well as ion probe dating on single zircon grains suggest that the migmatites were metamorphosed at ca. $1880 \mathrm{Ma}$ during a single tectonometamorphic event. Since there is no evidence of any earlier event in the study area, it is assumed that $1880 \mathrm{Ma}$ is the approximate age of the peak metamorphic event. The fact that both conventional methods and ion probe analyses yielded the same age within error margins indicates that partial melting and formation of different leucosome generations occurred within a short time interval. Partial melting started under the peak conditions of metamorphism together with crystallization of garnet and growth of unzoned zircon rims, and continued during the decompression stage simultaneously with formation of cordierite.

The core ages of different zircons are heterogeneous, which results in a migmatite with mixed zircon inheritance. Such an inheritance has been observed in several granitic rocks (e.g. Williams et al. 1988, Chen \& Williams 1990).

\section{Geological implications}

The weakly zoned rims of probable magmatic origin yielded ages of 1951-1959 Ma. These ages may reflect an early magmatic event prior to the metamorphic events that was contemporaneous 
with the emplacement of the MORB-type metavolcanic rocks occurring in the Tonalite-Trondhjemite Migmatite Belt. In addition, the age of the Knaften granite (1954 $\pm 6 \mathrm{Ma}$ ) from a Svecofennian volcanic belt in northern Sweden falls within the same age group possibly indicating a rifting episode of a Svecofennian protocontinent. However, given the complexity of zircon ages in these migmatites and the limited number of analysed grains, it is possible also that the ca. $1950 \mathrm{Ma}$ ages are fortuitous.

According to Patiño Douce and Harris (1998), migmatites with K-poor leucosomes may represent the earliest appearance of melt during prograde metamorphism in a thickening orogenic belt. This is consistent with the studied rocks as they are characterized by K-poor leucosomes and occur in the Svecofennian domain with crust about $60 \mathrm{~km}$ thick at maximum (Korsman et al. 1999). The latter authors suggested that extensive magmatic underplating soon after subduction and crustal thickening during the Svecofennian Orogeny was the cause of the high-T/low-P metamorphism. The rapidly evolved magmatic underplating was caused by collision of the Svecofennian continent with the Archaean continent at $1885 \mathrm{Ma}$, when subduction was still going on in the southern Finland arc.

ACKNOWLEDGEMENTS: The studies by H.M. were funded by the Academy of Finland, Lithosphere Graduate School (financed by the Ministry of Education) and the Geological Survey of Finland. We would like to acknowledge the staffs of the units of Petrology, Mineralogy and Isotope Geology at the Espoo Office of the Geological Survey of Finland for discussions, assistance in the field and for mineral separation and chemistry and J.R. Kienast for supporting microprobe analyses and useful discussions. In addition, Jyrki Juhanoja was very helpful at the scanning electron microscope laboratory of the University of Helsinki. We would also like to thank Ilmari Haapala and M. Guiraud for useful discussions, and Leo Kriegsman, Matti Vaasjoki and Yrjö Kähkönen for their comments on the manuscript.

\section{REFERENCES}

Aranovich, L.Y. \& Newton, R.C. 1997. Phase equilibrium constraints on the granulite fluid composition. In: Hölttä P. (ed.) Mineral equilibria and data bases. Geological Survey of Finland, Guide 46, p. 9.

Aranovich, L.Ya. \& Podlesskii, K.K. 1983. The cordierite-garnet-sillimanite-quartz equilibrium: experiments and applications. In: Saxena, S. K. (ed.) Kinetics and Equilibrium in Mineral Reactions. Advances in Physical Geochemistry. New York: Springer, 173-198.

Bhattacharya, A., Mohanty, L., Maji, A., Sen, S.K. \& Raith, M. 1992. Non ideal mixing in the phlogopite-annite binary: constraints from experimental data on $\mathrm{Mg}-$ Fe partitioning and a reformulation of the biotite-garnet geothermometer. Contributions to Mineralogy and Petrology 111, 87-93.

Brown, M. 1979. The petrogenesis of the St. Malo migmatite belt, Armorican Massif, France, with particular reference to the diatexites. Neues Jahrbuch für Mineralogische Abhandlungen 135, 48-74.

Brown, M. 1983. The petrogenesis of some migmatites from the Presqu'ile de Rhuys, southern Brittany, France. In: Atherton, M.P. \& Gribble, C.D. (eds.) Migmatites, melting and metamorphism; Proceedings/Meeting High grade metamorphism, migmatites and melting of the Geochemical Group of the Mineralogical Society University of Glasgow, 174-200.

Burton, K.W. \& O’Nions, R.K. 1991. High-resolution garnet chronometry and the rates of metamorphic processes. Earth and Planetary Science Letters 107, 649-671.

Burton, K.W., Cohen, A.S. \& O'Nions, R.K. 1993. Nd, Sr and $\mathrm{Pb}$ diffusion in garnet. Terra Abstracts 5, p. 382.

Busch, W., Schneider, G. \& Mehnert, K.R. 1974. Initial melting at grain boundaries. Part II: Melting in rocks of granodioritic, quartzdioritic and tonalitic composition. Neues Jahrbuch für Mineralogie, Monatshefte 8, 345370 .

Chen, Y.D. \& Williams, I.S. 1990. Zircon inheritance in mafic inclusions from the Bega Batholith granites, southeastern Australia: an ion microprobe study. Journal of Geophysical Research 95 B, 17787-17796.

Chipera, S.J. \& Perkins, D. 1988. Evaluation of biotite-garnet geothermometers; application to the English River subprovince, Ontario. Contributions to Mineralogy and Petrology 98, 40-48.

Claesson, S., Huhma, H., Kinny, P.D. \& Williams, I.S. 1993. Svecofennian detrital zircon ages - implications for the Precambrian evolution of the Baltic Shield. Precambrian Research 64, 109-130.

Clemens, J.D. \& Vielzeuf, D. 1987. Constraints on melting and magma production in the crust. Earth and Planetary Science Letters 86, 287-306.

Cohen, A.S., O`Nions, R.K., Siegenthaler, R. \& Griffin, W.L. 1988. Chronology of the pressure-temperature history recorded by granulite terrane. Contributions to Mineralogy and Petrology 98, 303-311.

Copeland, P., Parrish, R.R. \& Harrison, T.M. 1988. Iden- 
tification of inherited radiogenic $\mathrm{Pb}$ in monazite and its implications for U-Pb systematics. Nature 333, 760-763.

DeWolf, C.P., Belshaw, N.S. \& O'Nions, R.K. 1993. A metamorphic history from micron-scale ${ }^{207} \mathrm{~Pb} /{ }^{206} \mathrm{~Pb}$ chronometry of Archean monazite. Earth and Planetary Science Letters 120, 207-220.

DeWolf, C.P., Zeissler, C.J., Halliday, A.N., Mezger, K. \& Essene, E.J. 1996. The role of inclusions in U-Pb and Sm-Nd garnet geochronology; stepwise dissolution experiments and trace uranium mapping by fission track analysis. Geochimica et Cosmochimca Acta 60, 121134.

Ferry, J.M. \& Spear, F.S. 1978. Experimental calibration of the partitioning of $\mathrm{Fe}$ and $\mathrm{Mg}$ between biotite and garnet. Contributions to Mineralogy and Petrology 66, 113-117.

Ganguly, J., Tirone, R. \& Hervig, R.L. 1998. Diffusion kinetics of samarium and neodymium in garnet and method for determining cooling rates of rocks. Science 281, 805-807.

Gebauer, D. \& Grünenfelder, M. 1979. U-Pb-Th dating of minerals. In: Jäger, E. \& Hunziker, J.C. (eds.) Lectures in Isotope Geology. Berlin: Springer, 105-131.

Glebovitskiy, V.A. 1970. Process of regional metamorphism and ultrametamorphism and some problems of the geology of the deep lying sections of folded zones. International Geological Review 12, 681-690.

Hanchar, J.M. \& Miller, C.F. 1993. Zircon zonation patterns as revealed by cathodoluminescence and back-scattered electron images: implications for interpretation of complex crustal histories. Chemical Geology 110, 1-13.

Hanchar, J. \& Rudnick, R.L. 1995. Revealing hidden structures: the application of cathodoluminescence and backscattered electron imaging to dating zircons from lower crustal xenoliths. Lithos 36, 289-303.

Hensen, B.J. \& Zhou, B. 1995. A Pan-African granulite facies metamorphic episode in Prydz Bay, garnet dating. Australian Journal of Earth Sciences 42, 249-258.

Hodges, K.V. \& Spear, F.S. 1982. Geothermometry, geobarometry and the $\mathrm{Al}_{2} \mathrm{Si}_{3} \mathrm{O}_{5}$ triple point at Mt. Moosilauke, New Hampshire. American Mineralogist 67, 1118-1134.

Holdaway, M.J. 1971. Stability of andalusite and aluminium silicate phase diagram. American Journal of Science 271, 97-131.

Holmes, A. 1954. The oldest dated minerals of the Rhodesian Shield. Nature 173, 612-617.

Huhma, H., Claesson, S., Kinny, P.D. \& Williams, I.S. 1991. The growth of Early Proterozoic crust: new evidence from Svecofennian detrital zircons. Terra Nova 3, 175-178.

Jacobs, J., Fanning, C.M., Henjes-Kunst, F., Olesch, M. \& Paech, H.-J. 1998. Continuation of the Mozambique Belt into East Antarctica; Grenville-age metamorphism and polyphase Pan-African high-grade events in central Dronning Maud Land. Journal of Geology 106, 385-406.

Jagoutz, E. 1988. Nd and Sr systematics in an eclogite xenolith from Tanzania: evidence from frozen mineral equilibria in the continental lithosphere. Geochimica et Cosmochimca Acta 52, 1285-1293.

Johannes, W. 1978. Melting of plagioclase in the system $\mathrm{Ab}-\mathrm{An}-\mathrm{H}_{2} \mathrm{O}$ and $\mathrm{Qz}-\mathrm{Ab}-\mathrm{An}-\mathrm{H}_{2} \mathrm{O}$ at $\mathrm{P}_{\mathrm{H} 2 \mathrm{O}}=5$ kbars, an equilibrium problem. Contributions to Mineralogy and Petrology 66, 295-303.

Johannes, W. \& Gupta, L.N. 1982. Origin and evolution of a migmatite. Contributions to Mineralogy and Petrology 79, 114-123.

Jones, K. A. \& Brown, M. 1990. High-temperature "clockwise" P-T paths and melting in the development of regional migmatites; an example from southern Brittany, France. Journal of Metamorphic Geology 8, 551-578.

Kähkönen, Y., Huhma, H. \& Aro, K. 1989. U-Pb zircon ages and $\mathrm{Rb}$-Sr whole rock isotope studies of early Proterozoic volcanic and plutonic rocks near Tampere, southern Finland. Precambrian Research 45, 27-43.

Kilpeläinen, T. 1998. Evolution and 3D modelling of structural and metamorphic patterns of the Palaeoproterozoic crust in the Tampere-Vammala area, southern Finland. Geological Survey Finland, Bulletin 397. 124 p.

Kilpeläinen, T., Korikovsky, S., Korsman, K. \& Nironen, M. 1994. Tectono-metamorphic evolution in the Tampere-Vammala area. Geological Survey of Finland, Guide 37, 27-34.

Kinney, P.D., Williams, I.S., Froud, D.O., Irland, T.R. \& Compston, W. 1988. Early Archean zircon ages from orthogneiss and anorthosites at Mount Narryer, Western Australia. Precambrian Research 38, 325-341.

Korsman, K. 1977. Progressive metamorphism of the metapelites in the Rantasalmi-Sulkava area, southeastern Finland. Geological Survey of Finland, Bulletin 290. $82 \mathrm{p}$.

Korsman, K., Korja, T. \& Virransalo, P. 1997a. Global Geoscience Transect programme in Finland: The GGT/ SVEKA transect. In: H. Dawei (ed.) Structure of the Lithosphere and Deep Processes. Proceedings of the $30^{\text {th }}$ International Geological Congress 4, 77-90.

Korsman, K., Koistinen, T., Kohonen, J., Wennerström, M., Ekdahl, E., Honkamo, M., Idman, H. \& Pekkala, Y. (eds.) 1997b. Suomen kallioperäkartta - Bedrock Map of Finland, 1: 1000 000. Espoo: Geological Survey of Finland.

Korsman, K., Korja, T., Pajunen, M., Virransalo, P. \& the GGT/SVEKA Working Group 1999. The GGT/SVEKA Transect - structure and evolution of the continental crust in the Paleoproterozoic Svecofennian Orogen in Finland. International Geology Review 41, 287-333.

Krogh, T.E. 1973. A low-contamination method for hydrothermal decomposition of zircon and extraction of $U$ and $\mathrm{Pb}$ for isotopic age determinations. Geochimica et Cosmochimica Acta 37, 485-494.

Lahtinen, R. 1994. Crustal evolution of the Svecofennian and Karelian domains during 2.1-1.79 Ga, with special emphasis on the geochemistry and origin of 1.93-1.91 $\mathrm{Ga}$ gneissic tonalites and associated supracrustal rocks in the Rautalampi area, central Finland. Geological Survey of Finland, Bulletin 378. 128 p. 
Le Breton, N. \& Thompson, A.B. 1988. Fluid-absent (dehydration) melting of biotite in metapelites in the early stages of crustal anatexis. Contributions to Mineralogy and Petrology 99, 226-237.

Ludwig, K.R. 1998. Using Isoplot/Ex, version 1.00: a geochronological toolkit for Microsoft Excel. Berkeley Geological Center, Special Publication No 1.40 p.

Mehnert, K.R. 1968. Migmatites and the Origin of Granitic Rocks. Amsterdam: Elsevier. 393 p.

Mezger, K., Hanson, G.N. \& Bohlene, S.R. 1989. U-Pb systematics of garnet: dating the growth of garnet in the Late Archean Pikwitonei granulite domain at Cauchon and Natawahuna Lakes, Manitoba, Canada. Contributions to Mineralogy and Petrology 101, 136-148.

Mezger, K., Essene, E.J. \& Halliday, A.N. 1992. Closure temperature of the Sm-Nd system in metamorphic garnets. Earth and Planetary Science Letters 113, 397-409.

Nabelek, P.I. Glascock, M.D. \& Michael, D. 1995. REEdepleted leucogranites as a consequence of disequilibrium melting of monazite-bearing schists, the Black Hills, South Dakota. In: Brown, M. \& Piccoli, P.M. (eds.) The origin of granites and related rocks. U.S. Geological Survey Circular 1129, 103-104.

Nironen, M. 1989. Emplacement and structural setting of granitoids in the early Proterozoic Tampere and Savo Schist Belts, Finland - implications for contrasting crustal evolution. Geological Survey of Finland, Bulletin $346.83 \mathrm{p}$.

Parrish, R.R. 1990. U-Pb dating of monazite and its application to geologic problems. Canadian Journal of Earth Sciences 27, 1431-1450.

Patchett, P.J. \& Ruiz, J. 1987. Nd isotopic ages of crust formation and metamorphism in the Precambrian of eastern and southern Mexico. Contributions to Mineralogy and Petrology 96, 523-528.

Paterson, B.A., Stephen, W.E., Rogers, W., Williams, I.S., Hinton, R.W. \& Herd, D.A. 1992. The nature of zircon inheritance in two granite plutons. Transactions of the Royal Society of Edinburgh: Earth Sciences 83, 459471.

Patiño Douce, A.E. \& Beard, J.S. 1995. Dehydration-melting of biotite gneiss and quartz amphibolite from 3 to 15 kbar. Journal of Petrology 36, 707-738.

Patiño Douce, A.E. \& Harris, N. 1998. Experimental constraints on the Himalayan anatexis. Journal of Petrology $39,689-710$.

Peltonen, P. 1995. Petrogenesis of ultramafic rocks in the Vammala nickel belt; implications for crustal evolution of the early Proterozoic Svecofennian arc terrane. Lithos 34, 253-274.

Peltonen, P., Kontinen, A. \& Huhma, H. 1996. Petrology and geochemistry of metabasalts from the 1.95 Ga Jormua ophiolite, northeastern Finland. Journal of Petrology $37,1359-1383$.

Perchuk, L.L. \& Lavrentèva, I.V. 1983. Experimental investigation of exchange equilibria in the system cordierite-garnet-biotite. In: Saxena, S.K. (ed.) Kinetics and Equilibrium in Mineral Reactions. New York: Spring- er, 199-239.

Pidgeon, R.T. \& Aftalion, M. 1978. Cogenetic and inherited zircon $\mathrm{U}-\mathrm{Pb}$ systems in granites: Palaeozoic granites of Scotland and England. In: Bowes, D.R. \& Leake, B.E. (eds.) Crustal evolution in Northwestern Britain and adjacent regions. Geological Journal, Special Issue 10, 183-220.

Pidgeon, R.T. 1992. Recrystallisation of oscillatory zoned zircon: some geochronological and petrological implications. Contributions to Mineralogy and Petrology 110, 463-472.

Pidgeon, R.T. \& Wilde, S.A. 1998. The intepretation of complex zircon U-Pb systems in Archaean granitoids and gneisses from the Jack Hills, Narryer Gneiss Terrane, Western Australia. Precambrian Research. 91, 309332.

Poller, U., Liebetrau, V. \& Todt, W. 1997. U-Pb singlezircon dating under cathodoluminescence control (CLCmethod): application to polymetamorphic orthogneisses. Chemical Geology 139, 287-299.

Powell, R. \& Holland, T.J.B. 1988. An internally consistent dataset with uncertainties and correlations: 3. Applications to geobarometry, worked examples and a computer program. Journal of Metamorphic Geology 6, 173204.

Selverstone, J. \& Hollister, L.S. 1980. Cordierite-bearing granulites from the Coast Ranges, British Columbia: P$\mathrm{T}$ conditions of metamorphism. Canadian Mineralogist $18,119-129$.

Spear, F.S. 1993. Metamorphic phase equilibria and pressure-temperature-time paths. Mineralogical Society of America. 799 p.

Spear, F.S. \& Parrish, R.R. 1996. Petrology and cooling rates of the Valhalla Complex, British Columbia. Canadian Journal of Petrology 37, 733-765.

Stacey, J.S. \& Kramers, J.D. 1975. Approximation of terrestrial lead isotope evolution by a two-stage model. Earth and Planetary Science Letters 26, 207-221.

Vaasjoki, M. \& Huhma, H. 1999. Lead and neodymium isotopic results from metabasalts of the Haveri Formation, southern Finland: evidence for Palaeoproterozoic enriched mantle. Bulletin of the Geological Society of Finland 71, 143-153. (this volume)

Vance, D. \& O'Nions, R.K. 1990. Isotopic chronometry of zoned garnets: growth kinetics and metamorphic histories. Earth and Planetary Science Letters 97, 227-240.

Vavra, G., Gebauer, D., Schmid, R. \& Compston, W. 1996. Multiple zircon growth and recrystallization during polyphase Late Carboniferous to Triassic metamorphism in granulites of the Ivrea Zone (Southern Alps): an ion microprobe (SHRIMP) study. Contributions to Mineralogy and Petrology 122, 337-358.

Vernon, R.H. \& Collins, W.J. 1988. Igneous microstructures in migmatites. Geology 16, 1126-1130.

Vielzeuf, D. \& Holloway, J.R. 1988. Experimental determination of the fluid-absent melting relations in the pelitic system. Consequences for crustal differentiation. Contributions to Mineralogy and Petrology 98, 257-276. 
Vry, J., Compston, W. \& Cartwright, I. 1996. SHRIMP II dating of zircons and monazites: reassessing the timing of high-grade metamorphism and fluid flow in the Reynolds Range, northern Arunta Block, Australia. Journal of Metamorphic Geology 14, 335-350.

Wasström, A. 1993. The Knaften granitoids of Västerbotten Country, northern Sweden. In: Lundqvist, Th. (ed.) Radiometric dating results. Geological Survey of Sweden, Research Papers C 823, 60-64.

Watson, E.B. \& Harrison T.M. 1983. Zircon saturation revisited: temperature and composition effects in a variety of crustal magma types. Earth and Planetary Science Letters 64, 295-304.

Whitehouse, M., Claesson, S., Sunde, T. \& Vestin, S. 1997. Ion microprobe $\mathrm{U}-\mathrm{Pb}$ zircon geochronology and corre- lation of Archaean gneisses from the Lewisian Complex of Gruinard Bay, northwestern Scotland. Geochimica et Cosmochimica Acta 61, 4429-4438.

Whitney, D.L. \& Irving, A.J. 1994. Origin of K-poor leucosomes in a metasedimentary migmatite omplex by ultrametamorphism, syn-metamorphic magmatism and subsolidus processes. Lithos 32, 173-192.

Williams, I.S., Chen, Y., Chappell, B.W. \& Compston, W. 1988. Dating sources of Bega Batholith granites by ion microprobe. Geological Society of Australia, Abstracts 2, 424 .

Williams, M.L. \& Grambling, J.A. 1991. Manganese, ferric iron and the equilibrium between garnet and biotite. American Mineralogist 75, 886-908. 